\title{
Managing a Destructive, Episodic Crop Disease: A National Survey of Wheat and Barley Growers' Experience With Fusarium Head Blight
}

\author{
Christina Cowger, ${ }^{1, \dagger}$ Joy Smith, ${ }^{2}$ Dennis Boos, ${ }^{2}$ Carl A. Bradley, ${ }^{3}$ Joel Ransom, ${ }^{4}$ and Gary C. Bergstrom ${ }^{5}$ \\ ${ }^{1}$ U.S. Department of Agriculture Agricultural Research Service, Department of Plant Pathology, North Carolina State University, \\ Raleigh, NC 27695 \\ ${ }^{2}$ Department of Statistics, North Carolina State University, Raleigh, NC 27695 \\ ${ }^{3}$ Department of Plant Pathology, University of Kentucky Research and Education Center, Princeton, KY 42445 \\ ${ }^{4}$ Department of Plant Sciences, North Dakota State University, Fargo, ND 58108-6050 \\ ${ }^{5}$ Plant Pathology and Plant-Microbe Biology Section, School of Integrative Plant Science, Cornell University, Ithaca, NY 14853
}

\begin{abstract}
The main techniques for minimizing Fusarium head blight (FHB, or scab) and deoxynivalenol in wheat and barley are well established and generally available: planting of moderately FHB-resistant cultivars, risk monitoring, and timely use of the most effective fungicides. Yet the adoption of these techniques remains uneven across the FHB-prone portions of the U.S. cereal production area. A national survey was undertaken by the U.S. Wheat and Barley Scab Initiative in 17 states where six market classes of wheat and barley are grown. In 2014, 5,107 usable responses were obtained. The highest percentages reporting losses attributable to FHB in the previous 5 years were in North Dakota, Maryland, Kentucky, and states bordering the Great Lakes but across all states, $\geq 75 \%$ of respondents reported no FHB-related losses in the previous 5 years. Adoption of cultivar resistance was uneven by state and market class and was low except among hard red spring wheat growers. In 13 states, a majority of respondents had not
\end{abstract}

Abstract applied an FHB-targeted fungicide in the previous 5 years. Although the primary FHB information source varied by state, crop consultants were considered to be an important source or their primary source of information on risk or management of FHB by the largest percentage of respondents. Use of an FHB risk forecasting website was about twice as high in North Dakota as the 17 -state average of $6 \%$. The most frequently cited barriers to adopting FHB management practices were weather or logistics preventing timely fungicide application, difficulty in determining flowering timing for fungicide applications, and the impracticality of FHB-reducing rotations. The results highlight the challenges of managing an episodically damaging crop disease and point to specific areas for improvement.

Keywords: cereals and grains, chemical, cultivar/resistance, disease management, disease warning systems, epidemiology, field crops, fungi
Fusarium head blight (FHB, or scab) of wheat (Triticum aestivum L.) and barley (Hordeum vulgare L.) is a much-studied disease that lowers grain yield and contaminates grain with mycotoxins such as deoxynivalenol (DON). In the United States, the disease is mainly caused by Fusarium graminearum Schwabe sensu lato, a fungal pathogen with a wide host range. The U.S. Food and Drug Administration (2010) has set $1 \mu \mathrm{g} / \mathrm{g}$ as the advisory ceiling for DON in finished wheat products such as flour and bran that are intended for the human food supply.

The U.S. Wheat and Barley Scab Initiative (USWBSI) has been active since 1997 as a stakeholder-driven research initiative aimed at identifying and publicizing research-based solutions to the FHB problem (McMullen et al. 2012). Practices demonstrated by research to be most effective in managing FHB are planting moderately resistant (MR) cultivars, monitoring risk, and applying fungicides when risk is elevated. Ratings of cultivar resistance are broadly available.

${ }^{\dagger}$ Corresponding author: C. Cowger; Christina.Cowger@ars.usda.gov

Funding: This work was supported by the U.S. Wheat and Barley Scab Initiative.

*The $\boldsymbol{e}$-Xtra logo stands for "electronic extra" and indicates that seven supplementary tables are published online.

The author(s) declare no conflict of interest.

Accepted for publication 24 September 2019.

This article is in the public domain and not copyrightable. It may be freely reprinted with customary crediting of the source. The American Phytopathological Society, 2020.
Other recommended management practices that have some effect include cultivar rotation and spreading out flowering times by staggering planting dates and/or choosing varieties with varying maturities.

In the United States, forecasts of FHB risk are available for spring or winter wheat in 35 states at the national Fusarium Head Blight Prediction Center (http://www.wheatscab.psu.edu) supported by the USWBSI. Both spring and winter wheat models take cultivar resistance into account. Risk of an epidemic with $>10 \%$ severity is estimated based on relative humidity, and the models are accurate about 70 to $80 \%$ of the time (McMullen et al. 2012).

National multilocation fungicide trials comparing tebuconazole (Folicur; Bayer CropScience), propiconazole (Tilt; Syngenta Crop Protection), prothioconazole (Proline; Bayer CropScience), tebuconazole plus prothioconazole (Prosaro; Bayer CropScience), and metconazole (Caramba; BASF) generated 12 years of data from 14 U.S. states (Paul et al. 2010). The products leading to the highest mean increase in yield and test weight relative to the check were, in order, metconazole (Caramba), prothioconazole (Proline), and prothioconazole plus tebuconazole (Prosaro). Uniform fungicide trials showed that quinone outside inhibitor (QoI) application at flag, boot, and heading growth stages led to a moderate or low percentage of control of disease symptoms (shown in Fig. 1) compared with the best treatments but significantly higher DON relative to the nontreated control (Paul et al. 2018). Even QoI plus demethylation inhibitor (DMI; triazole) mixed products applied at heading sometimes increased DON compared with the untreated control (Paul et al. 2018).

To assess the adoption of best FHB management practices, a national survey was conducted to better understand how wheat and barley growers approach management of this disease. The survey was approved by the Office of Management and Budget (control number 
0535-0252) and sponsored by the USWBSI. The U.S. Department of Agriculture National Agricultural Statistics Service (NASS) conducted the sampling and administration of the questionnaire. Previously, basic information was lacking on topics such as crop area by cultivar, whether and how growers obtain information about FHB and its management, level of priority assigned by growers to FHB management, access to cultivar ratings and seed of resistant cultivars, the main incentives driving decisions about FHB management (such as the extent and rate of rejection and/or dockage in FHB years), and changes in incentives, pricing, discounts, seed availability, and policy that might encourage adoption.

Among the questions the survey sought to address were the following:

- With what frequency are recommended FHB management techniques adopted, and does adoption vary among market classes and states?

- What barriers to adoption are most frequently experienced?

- How does perceived frequency and magnitude of FHB-related losses affect adoption?

- Does the type of FHB information source or guidance that is preferred affect growers' rate of adoption of management practices?

- Is adoption of FHB management techniques associated with higher yields?

- Do farm size, education level, and/or farming experience correlate with higher adoption of FHB management practices?

- And how do all these factors vary among barley growers and by market class of wheat?

Although data are available on planted and harvested area by cultivar for the hard wheat and durum wheat area, in most soft winter wheat states there are no data on wheat or barley area by cultivar and thus no good estimates of area planted to FHB-resistant cultivars. We hypothesized that the share of area planted to MR cultivars was low in some states and market classes, particularly in the soft winter wheat area. We also hypothesized that effective use of risk forecasts and fungicides was low relative to need.

\section{Materials and Methods}

Survey design. The survey was prepared for growers of six grain market classes: barley, durum wheat, hard red spring (HRS) wheat, hard red winter (HRW) wheat, soft red winter (SRW) wheat, and soft white winter (SWW) wheat. A small amount of hard white spring (HWS) and hard white winter (HWW) wheat was included in the HRS and HRW classes, respectively. A four-page questionnaire (Supplementary Table S1) was developed with grower input by a team that included small-grain pathologists, an agricultural economist with survey experience, and two growers. The instrument included questions about cultivars and hectarage planted,

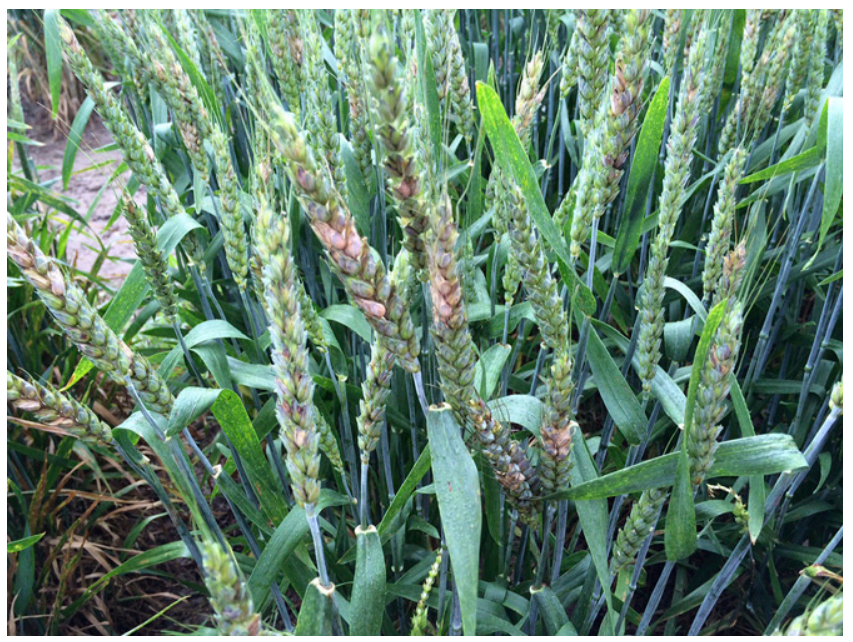

Fig. 1. Symptoms of Fusarium head blight in soft red winter wheat. (Photo credit: Stephen A. Harrison, Louisiana State University.) management practices used, sources of information, and demographic questions such as farm size, education, employees, and experience.

The 17 states to be surveyed were selected on the basis of having significant area of wheat and barley and having a history of FHB problems. To select the sample in the targeted states, NASS began by considering a total of 115,082 farming operations, ranging from a low of 1,553 in New York to a high of 19,400 in Kansas (Supplementary Table S2). Operations included were those that planted wheat and no barley, those that planted barley and no wheat, and those that planted both. From that population, the NASS selected a stratified sample to represent all sizes of operations, the various market classes, and all geographic regions of each of the 17 states (Fig. 2). To adequately address all of those criteria, a larger percentage of operations was selected in states with fewer growers.

The NASS administered the survey in February and March 2014 to a potential sample of 15,895 growers in 17 states (Supplementary Table S2). The survey was conducted via a physical mailing and subsequent telephone enumeration. As a result of technical problems with the original sample from Kentucky, a second sample was drawn and the survey was administered to those growers in August and early September 2014.

Analysis of raw survey data. Data were analyzed anonymously; each participant was tracked only by a random identification (ID) number. The NASS provided 8,454 surveys and 5,107 were used in the data analysis; surveys were considered usable if the participant answered at least one of the 136 FHB-related questions on the survey. The usable surveys represented 5,107 farms with 5,066 farmer IDs in 17 states; in a few cases, a single grower reported on more than one farm. The response rate per state varied from 17 (Virginia) to $44 \%$ (Ohio) (Supplementary Table S2). The total number of farms that reported harvesting barley for grain in the previous 5 years was 1,335 (26\%); of those, 1,080 (about $81 \%$ ) provided information on area of cultivars produced. The total number of farms that harvested wheat for grain during that period was 4,683 (92\%); of those, 3,797 farms $(81 \%)$ provided information on area of cultivars produced.

Population estimates were made with the weights defined by the usual weights for stratified sampling. These weights are essentially of the form $N_{h} / n_{h}$, where $N_{h}$ is the population size (number of farms) in the $h$ th stratum and $n_{h}$ is the number of farms in the sample in the $h$ th stratum. Because of nonresponse, these weights were adjusted by replacing $n_{h}$ with $n_{h}{ }^{*}$, the number of respondents in the $h$ th stratum. However, no other adjustments were made for nonresponse or missing values.

Cultivar area. In a free-response question, growers were asked how many acres were planted of the top three cultivars they had grown in each market class the last time wheat or barley had been harvested for grain. Acres were converted to hectares for reports. In

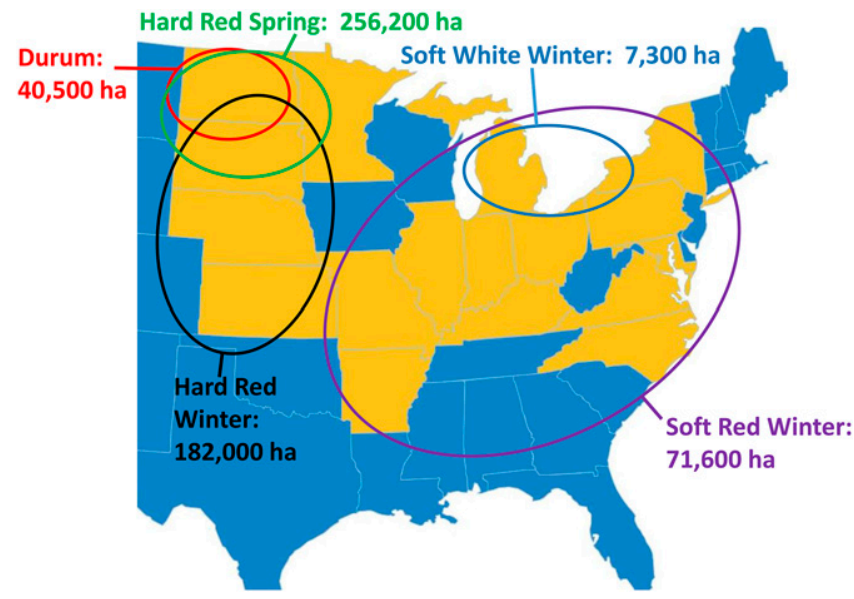

Fig. 2. Seventeen states (light color) where wheat and barley growers were surveyed on management of Fusarium head blight in 2014, and the approximate area of the top three varieties they each reported having grown most recently, by wheat market class. An additional approximately 68,400 hectares $(169,000$ acres) of barley were reported, $81 \%$ of them in North Dakota and Minnesota. 
cases where the volunteered cultivar name did not match the market class under which it was entered, the cultivar was assumed to be correct and the market class was altered to the correct one.

Cultivar names were compiled in each market class, and all available data from public sources on FHB resistance rating was compiled in order to assign a rating of MR, moderately susceptible (MS), or susceptible (S). This allowed the crop area data from respondents to be categorized at one of those levels, as an "unknown cultivar" when the cultivar could not be identified, or as "unknown resistance" if no public information on resistance level was available.

When these data were tabulated, ranges rather than exact values of crop area had to be reported in some cases, because confidentiality rules prevented disclosure of exact data where individual cell totals were based on an excessively small number of respondents or contained a single excessively large value. In a given row or column, the suppression of one exact value also required the suppression of a complementary value in another cell, to prevent derivation of the originally suppressed value. The purpose of those rules was to prevent identification of individuals.

Statistical analysis and predictors of management practice use. The data analysis was performed using SAS version 9.4.
Population percentage estimates were obtained using PROC SURVEYMEANS and PROC SURVEYFREQ with strata, weight, and domain statements. The individual standard errors were all calculated assuming stratified random sampling with the respondent sample sizes. Maximum standard errors of estimates are reported by state or as otherwise noted in the tables.

\section{Results}

Experience of FHB losses. Growers were asked how many years out of the previous 5 years FHB had reduced yields, caused a problem with DON (vomitoxin), or caused dockage or grain rejection. Across the 17 states, the problem experienced in $\geq 2$ years by the largest percentage of growers $(13 \%)$ was yield reduction, whereas DON and dockage or rejection were reported in $\geq 2$ years by 6 and $5 \%$ of all respondents, respectively (Table 1). Yield reduction in $\geq 2$ of the past 5 years was reported most frequently by growers in North Dakota and the northern soft wheat states of Kentucky, Ohio, Illinois, Indiana, Maryland, and Pennsylvania. In those states, 16 to $22 \%$ of respondents reported experiencing yield reduction attributable to FHB in $\geq 2$ of the last 5 years. Michigan, although also in the northern soft wheat region, was an outlier,

Table 1. The number of years growers in 17 states experienced three main negative impacts of Fusarium head blight on wheat or barley crops ${ }^{\mathrm{a}}$

\begin{tabular}{|c|c|c|c|c|c|c|c|c|c|c|c|c|c|c|c|c|}
\hline \multirow[b]{3}{*}{ State } & \multicolumn{15}{|c|}{ Years out of past 5 years ${ }^{b}$} & \multirow[b]{3}{*}{ Maximum SE } \\
\hline & \multicolumn{5}{|c|}{ Reduced yields } & \multicolumn{5}{|c|}{ A problem with DON (vomitoxin) } & \multicolumn{5}{|c|}{ Dockage or grain rejection } & \\
\hline & $\mathbf{0}$ & 1 & $2-3$ & $4-5$ & Ind. & $\mathbf{0}$ & 1 & $2-3$ & $4-5$ & Ind. & $\mathbf{0}$ & 1 & $2-3$ & $4-5$ & Ind. & \\
\hline Arkansas & 95 & 4 & 1 & - & - & 98 & 1 & - & - & 1 & 97 & 2 & - & - & 1 & 2.5 \\
\hline Kansas & 93 & 3 & 3 & 0 & 1 & 98 & 1 & 1 & - & 1 & 97 & 2 & 1 & - & 1 & 1.3 \\
\hline Nebraska & 90 & 6 & 2 & 1 & 1 & 96 & 2 & 1 & - & 1 & 96 & 2 & 0 & - & 1 & 2.1 \\
\hline Virginia & 70 & 14 & 7 & 0 & 9 & 79 & 9 & 3 & - & 9 & 81 & 9 & 2 & - & 8 & 4.6 \\
\hline South Dakota & 83 & 8 & 7 & 1 & 0 & 92 & 5 & 3 & - & 0 & 91 & 6 & 2 & 0 & 0 & 2.1 \\
\hline Michigan & 79 & 11 & 5 & 3 & 1 & 80 & 11 & 6 & 2 & 1 & 85 & 11 & 3 & 1 & 1 & 2.3 \\
\hline North Carolina & 75 & 9 & 9 & 1 & 6 & 82 & 9 & 4 & 1 & 5 & 83 & 9 & 2 & - & 6 & 3.2 \\
\hline New York & 65 & 15 & 9 & 1 & 9 & 63 & 17 & 8 & 1 & 10 & 70 & 16 & 4 & - & 9 & 3.7 \\
\hline Minnesota & 78 & 8 & 9 & 3 & 2 & 92 & 5 & 2 & 1 & 1 & 93 & 5 & 1 & 0 & 1 & 2.6 \\
\hline Missouri & 72 & 11 & 13 & 3 & 1 & 89 & 4 & 5 & - & 2 & 86 & 6 & 7 & - & 1 & 2.8 \\
\hline Pennsylvania & 68 & 10 & 11 & 5 & 6 & 73 & 11 & 8 & 3 & 5 & 77 & 10 & 6 & 2 & 4 & 2.4 \\
\hline Maryland & 65 & 18 & 9 & 7 & 1 & 76 & 11 & 6 & 5 & 1 & 78 & 13 & 4 & 5 & 0 & 3.3 \\
\hline Indiana & 67 & 13 & 13 & 4 & 3 & 77 & 14 & 6 & 1 & 2 & 79 & 12 & 6 & 2 & 2 & 3.1 \\
\hline Illinois & 66 & 10 & 15 & 5 & 4 & 86 & 6 & 4 & 2 & 2 & 83 & 7 & 7 & 1 & 1 & 3.0 \\
\hline Ohio & 59 & 17 & 15 & 5 & 2 & 64 & 23 & 10 & 1 & 2 & 75 & 16 & 8 & 1 & 1 & 2.4 \\
\hline Kentucky & 59 & 19 & 14 & 7 & 0 & 74 & 19 & 4 & 3 & 0 & 74 & 19 & 4 & 3 & - & 4.4 \\
\hline North Dakota & 68 & 10 & 14 & 7 & 0 & 82 & 8 & 7 & 3 & 0 & 86 & 6 & 5 & 3 & 0 & 1.9 \\
\hline Total & 75 & 10 & 10 & 3 & 2 & 83 & 9 & 5 & 1 & 2 & 85 & 8 & 4 & 1 & 2 & 0.7 \\
\hline
\end{tabular}

a Table entries are estimated percentages of growers. $\mathrm{SE}=$ maximum standard error of the estimates. Estimates are not reported where sample sizes were too small to calculate a standard error.

b Years were 2009 to 2013 except in Kentucky, where they were 2010 to 2014. DON = deoxynivalenol and Ind. = indeterminate number of years.

Table 2. Small grain cultivar area reported by operators of 5,107 farms in 17 states, shown by grain market class and level of Fusarium head blight (FHB) resistance $^{\mathrm{a}}$

\begin{tabular}{|c|c|c|c|c|c|c|c|c|c|c|c|}
\hline \multirow[b]{3}{*}{$\begin{array}{l}\text { Market } \\
\text { class }^{\text {b }}\end{array}$} & \multicolumn{8}{|c|}{ Level of FHB resistance ${ }^{c}$} & \multirow{2}{*}{\multicolumn{2}{|c|}{ Unknown cultivar ${ }^{d}$}} & \multirow[b]{3}{*}{$\begin{array}{c}\text { Total } \\
\text { hectarage }\end{array}$} \\
\hline & \multicolumn{2}{|c|}{ MR } & \multicolumn{2}{|c|}{ MS } & \multicolumn{2}{|c|}{$\mathbf{S}$} & \multicolumn{2}{|c|}{ Unknown resistance } & & & \\
\hline & Hectarage & $\begin{array}{c}\text { Row total } \\
\text { hectarage } \\
(\%)\end{array}$ & Hectarage & $\begin{array}{c}\text { Row total } \\
\text { hectarage } \\
(\%)\end{array}$ & Hectarage & $\begin{array}{c}\text { Row total } \\
\text { hectarage } \\
(\%)\end{array}$ & Hectarage & $\begin{array}{c}\text { Row total } \\
\text { hectarage } \\
(\%)\end{array}$ & Hectarage & $\begin{array}{c}\text { Row total } \\
\text { hectarage } \\
(\%)\end{array}$ & \\
\hline HRS & 121,199 & 47 & $\geq 60,703$ & $\geq 24$ & 23,386 & 9 & $202-404$ & $<1$ & $14,164-22,257$ & $6-9$ & 256,094 \\
\hline Durum & 11,741 & 29 & 14,743 & 36 & 10,945 & 27 & $405-809$ & $1-2$ & $2,023-3,035$ & $5-8$ & 40,635 \\
\hline SWW & 1,559 & 21 & $41-101$ & $\sim 1$ & 1,689 & 23 & 41-101 & $\sim 1$ & 4,064 & 55 & 7,437 \\
\hline SRW & 11,020 & 15 & 14,744 & 21 & 9,547 & 13 & 1,630 & 2 & 34,735 & 49 & 71,676 \\
\hline HRW & 19,704 & 11 & 86,005 & 47 & 22,734 & 13 & 11,461 & 6 & 42,224 & 23 & 182,128 \\
\hline Barley & 5,188 & 8 & 28,871 & 42 & 24,316 & 36 & 4,240 & 6 & 5,711 & 8 & 68,326 \\
\hline Total & 170,412 & & 236,110 & & 92,616 & & 18,334 & & 108,824 & & 626,296 \\
\hline
\end{tabular}

a Respondents were asked to name the three cultivars with the most planted hectarage the last time wheat or barley was harvested for grain. Ranges are given in some cases rather than exact values because of confidentiality rules.

${ }^{\mathrm{b}} \mathrm{HRS}=$ hard red spring wheat, SWW = soft white winter wheat, SRW = soft red winter wheat, and HRW = hard red winter wheat.

${ }^{\mathrm{c}} \mathrm{MR}=$ moderately resistant, $\mathrm{MS}=$ moderately susceptible, and $\mathrm{S}=$ susceptible. Unknown resistance indicates that the cultivar was not rated for FHB resistance.

${ }^{\mathrm{d}}$ Unknown cultivar indicates that the cultivar was not identified as a result of problems with the respondent's recall or data entry. 
with only $8 \%$ of respondents reporting $\geq 2$ years of yield problems attributable to FHB.

The states with the highest frequency of DON problems were North Dakota, Maryland, Pennsylvania, and Ohio (Table 1). In these states, an estimated 10 to $11 \%$ of growers reported DON problems in $\geq 2$ of the last 5 years.

Overall, no problems with yield, DON, or dockage/rejection in the previous 5 years were reported by between 75 and $85 \%$ of those surveyed, depending on the problem, and $71 \%$ had none of those problems in the previous 5 years. The percentage of growers with indeterminate numbers of years was $2 \%$ overall in response to each of the three possible problems. However, two states (Virginia and New York) had relatively high percentages (8 to $10 \%$ ) of indeterminate responses for this question, which could have been attributable to problems with the enumeration process.

Adoption of MR cultivars. The survey indicated that adoption of cultivar resistance varied considerably by market class (Table 2 ). In each of the six market classes, the cultivars that growers reported as their top cultivars were assigned an FHB rating of MR, MS, S, "unknown resistance" (no FHB rating), or "unknown cultivar" based on all available data. Of the hectarage reported by respondents, the percentages of MR hectares were $47 \%$ for HRS wheat, $29 \%$ for durum, $21 \%$ for SWW wheat, $15 \%$ for SRW wheat, $11 \%$ for HRW wheat, and $8 \%$ for barley (Table 2). In each case, the remainder of the FHB-rated hectarage reported was in MS or S cultivars.

When considering those percentages, it should be noted that there were large disparities among market classes in the percentage of total hectares reported that could not be identified to cultivar. The following hectares were classified as "unknown cultivar": cases in which the grower reported an area of a market class but either could or would not specify the cultivar, the information given was uninterpretable, or what telephone enumerators recorded was unintelligible. Of total reported hectares in the survey, "unknown cultivar" comprised 6 to $9 \%$ for barley, durum, and HRS; $23 \%$ for HRW; $48 \%$ for SRW; and 41 to $63 \%$ for SWW (exact number withheld to protect confidentiality) (Table 2).

HRS and HWS wheat. Most of the HRS/HWS area in this survey (99\%) was in Minnesota, North Dakota, and South Dakota (Supplementary Table S3). This was the highest-hectarage market class in the survey and the market class with by far the highest adoption of MR cultivars (overall, $47 \%$ of reported hectares were MR) (Table 2). Within North Dakota, however, the percentage of MR hectares varied substantially among districts: northeastern districts had percentages of 63 to $73 \%$, whereas southern and northwestern districts had percentages in the 25 to $44 \%$ range (data not shown). A similar variability occurred in South Dakota, where the percentage of MR hectares was 57 to $65 \%$ in most districts but $11 \%$ in the Northwest district (data not shown).

In the major HRS states, proportions of hectarage in S cultivars tended to be low in all districts; the highest levels were 13 to $14 \%$ in northwest Minnesota and two North Dakota districts and 21\% in southwestern South Dakota. There was a low percentage $(<1 \%$; Supplementary Table S3) of reported HRS hectarage with an unknown rating, suggesting that currently grown cultivars are being effectively screened for FHB resistance in this market class.

Durum wheat. The majority of the durum hectarage reported in this study (97\%) was in North Dakota (Supplementary Table S4). For all durum, $29 \%$ of reported area was in MR cultivars (Table 2); for North Dakota, the figure was 21 to 36\% (data not shown). Overall, durum had a small percentage (1 to $2 \%$ ) of hectares with unknown resistance (Table 2), and this was attributable to a single cultivar (data not shown). Screening and rating of currently grown cultivars appeared to be effective in this market class.

SWW wheat. Only $21 \%$ of all reported SWW hectares were in MR cultivars (Table 2). About $69 \%$ of the reported crop area in this market class was in Michigan and New York, with most of that in Michigan (Supplementary Table S5). Michigan had 27\% MR hectares, and New York had 47\% MR hectares. Of Michigan's total reported SWW hectarage, the majority $(7,393$ hectares, or $72 \%$ ) was in the Saginaw Valley and Thumb district; there, $44 \%$ of reported hectarage was susceptible. Thus, that single district had a large impact on the overall balance of MR with other hectares of SWW. Overall, a relatively high percentage $(55 \%)$ of the reported SWW hectares in this survey were not identifiable to cultivar; a large fraction of that was likely susceptible (e.g., Nagelkirk 2013).

SRW wheat. Only $15 \%$ of reported SRW hectares were rated as MR (Table 3). The rate of MR cultivar adoption ranged widely in this market class, from $1 \%$ in Michigan up to $33 \%$ in New York. Of total SRW hectares, $49 \%$ could not be identified to cultivar, and the rate was fairly even across states (Table 3 ) and districts (not shown). In some states, such as Indiana, Ohio, and Pennsylvania, 62 to $69 \%$ of reported SRW hectares could not be identified to cultivar. It is likely that most of the unknown-cultivar area was susceptible to FHB, as a minority of commercial SRW wheat cultivars were MR to FHB (e.g., Bowman 2013; Kolb and Brucker 2013).

$H R W$ and $H W W$ wheat. MR hectarage was low overall in this market class (11\% of total reported area; Supplementary Table S6). Of the major HRW states, it was relatively high in South Dakota (34\%), high in Missouri (34 to 67\%), intermediate in Nebraska and Minnesota (10 to 20\%),

Table 3. Soft red winter wheat area by level of Fusarium head blight (FHB) resistance reported by growers ${ }^{\mathrm{a}}$

\begin{tabular}{|c|c|c|c|c|c|c|c|c|c|c|c|c|}
\hline \multirow[b]{3}{*}{ State/region } & \multicolumn{8}{|c|}{ Level of FHB resistance ${ }^{b}$} & & & & \\
\hline & \multicolumn{2}{|c|}{ MR } & \multicolumn{2}{|c|}{ MS } & \multicolumn{2}{|c|}{$\mathbf{S}$} & \multicolumn{2}{|c|}{ Unknown resistance } & \multicolumn{2}{|c|}{ Unknown cultivar ${ }^{c}$} & \multicolumn{2}{|c|}{ Total } \\
\hline & Hectarage & $\begin{array}{c}\text { Row total } \\
\text { hectarage } \\
(\%)\end{array}$ & Hectarage & $\begin{array}{c}\text { Row total } \\
\text { hectarage } \\
(\%)\end{array}$ & Hectarage & $\begin{array}{c}\text { Row total } \\
\text { hectarage } \\
(\%)\end{array}$ & Hectarage & $\begin{array}{c}\text { Row total } \\
\text { hectarage } \\
(\%)\end{array}$ & Hectarage & $\begin{array}{c}\text { Row total } \\
\text { hectarage } \\
(\%)\end{array}$ & Hectarage & $\begin{array}{c}\text { Table } \\
\text { hectarage } \\
(\%)\end{array}$ \\
\hline Arkansas & 900 & 21 & 645 & 15 & $405-809$ & $10-19$ & $809-1,214$ & $19-29$ & 1,310 & 31 & 4,193 & 6 \\
\hline Illinois & 1,436 & 17 & 1,747 & 21 & 621 & 7 & 285 & 3 & 4,427 & 52 & 8,516 & 12 \\
\hline Indiana & 771 & 15 & 754 & 15 & 41-101 & $1-2$ & $20-40$ & $<1$ & 3,333 & 67 & 4,972 & 7 \\
\hline Kentucky & 683 & 10 & $3,035-4,654$ & $47-71$ & 101-202 & $2-3$ & 0 & 0 & 2,613 & 40 & 6,518 & 9 \\
\hline Michigan & $41-101$ & $\sim 1$ & 2,036 & 23 & $2,023-3,035$ & $22-34$ & $20-40$ & $<1$ & 3,988 & 44 & 9,018 & 13 \\
\hline Maryland & 1,141 & 20 & 1,249 & 21 & 1,014 & 17 & 0 & 0 & 2,448 & 42 & 5,851 & 8 \\
\hline Missouri & 2,306 & 28 & 1,340 & 16 & $202-404$ & $2-5$ & $41-101$ & $\sim 1$ & 4,318 & 52 & 8,314 & 12 \\
\hline New York & 1,076 & 33 & 612 & 19 & 41-101 & $1-3$ & $20-40$ & $\sim 1$ & 1,491 & 45 & 3,305 & 5 \\
\hline North Carolina & 1,128 & 15 & 783 & 10 & 3,078 & 40 & $20-40$ & $<1$ & $2,023-3,035$ & $27-40$ & 7,645 & 11 \\
\hline Ohio & 387 & 5 & 1,476 & 21 & 276 & 4 & 107 & 2 & 4,891 & 69 & 7,137 & 10 \\
\hline Pennsylvania & 460 & 16 & 344 & 12 & 167 & 6 & 100 & 4 & 1,774 & 62 & 2,844 & 4 \\
\hline Virginia & 582 & 21 & $405-809$ & $15-30$ & 437 & 16 & $10-20$ & $<1$ & 1,255 & 46 & 2,747 & 4 \\
\hline $\begin{array}{l}\text { Kansas, } \\
\text { Minnesota, } \\
\text { North Dakota, } \\
\text { South Dakota }\end{array}$ & $41-101$ & $7-16$ & $202-404$ & $33-66$ & 0 & 0 & $41-101$ & $7-16$ & $202-404$ & $33-66$ & 616 & 1 \\
\hline Total & 11,020 & 15 & 14,542 & 21 & 9,547 & 13 & 4,027 & 2 & 34,478 & 49 & 71,676 & \\
\hline
\end{tabular}

a Respondents were asked to name the three cultivars with the most planted hectarage the last time wheat was harvested for grain. Ranges are given in some cases rather than exact values because of confidentiality rules.

${ }^{\mathrm{b}} \mathrm{MR}=$ moderately resistant, $\mathrm{MS}=$ moderately susceptible, and $\mathrm{S}=$ susceptible. Unknown resistance indicates that the cultivar was not rated for FHB resistance.

c Unknown cultivar indicates that the cultivar was not identified as a result of problems with the respondent's recall or data entry. 
low in North Dakota (8\%), and very low in Kansas (1\%). A high proportion of HRW area in this survey was MS (47\%).

In Kansas, which accounted for $40 \%$ of HRW hectares in this study, there was little difference in the proportions of MR/MS/S hectarage among the three districts (east, central, and west) of the state (data not shown). This suggested that FHB was not a major factor in cultivar selection even in the higher-rainfall eastern district of Kansas, which is not surprising because FHB is not a frequent problem there.

A relatively high proportion $(6 \%)$ of hectarage reported in this market class was of unknown resistance. Another $23 \%$ of total reported hectares were of unknown cultivar. It may be worthwhile to identify which popular HRW/HWW cultivars of unknown resistance are grown in districts vulnerable to FHB, and which are grown in districts where FHB is rarely or never a problem. This would help target additional screening efforts if they are needed.

Among soft wheat states (Kentucky, Maryland, Michigan, New York, Ohio, and Pennsylvania) where respondents reported HRW production, the cultivar was not identified for $92 \%$ of that hectarage (Supplementary Table S6). It seems likely that in many cases, the market class was recorded erroneously, and the respondents were actually growing SRW wheat. Of the remaining $8 \%$ of hectares for which the cultivar could be identified, $46 \%$ of hectares were of unknown FHB rating. This may indicate a lack of FHB ratings for cultivars being grown for locally sourced bread flour in these soft wheat states. Where "branded" varieties are common, it is also possible that the same genotype is rated for FHB under one brand name but not under another.

Barley. Across states, MR acres as a percentage of total reported barley acres were very low at $8 \%$ (Table 4). However, there was a large variation among the states with substantial barley acreage. As a percentage of reported barley acres in the state, MR varieties were 0 to $10 \%$ in Illinois, Kansas, Michigan, Minnesota, Missouri, North Dakota, Nebraska, New York, and Ohio (with many of those states also reporting very little barley); 15 to 25\% in Indiana, Maryland, and North Carolina; and 33 to $43 \%$ in Kentucky, Pennsylvania, South Dakota, and Virginia.

Together, North Dakota and Minnesota reported the largest barley area in this study (72 and 9\% of the total, respectively; Table 4). The percentage of moderate resistance was lower overall in these two states (3 to 6\%) but varied among districts, being highest in the Southwest, West Central, and South Central districts of North Dakota (11\%; data not shown).
Barley was one of two market classes with a substantial percentage $(6 \%)$ of reported acres planted to identifiable varieties with unknown resistance (Table 4). In the lower-acreage states (Illinois, Indiana, Kentucky, Michigan, Ohio, and New York), the FHB rating was unknown for $38 \%$ of the reported barley acreage, although it varied widely among those states. In Kansas, Missouri, Nebraska, and South Dakota, the percentage of total acres with unknown FHB resistance was 14 to $29 \%$. The Mid-Atlantic states (Maryland, North Carolina, Virginia, and Pennsylvania) did better, with just $8 \%$ of reported acres having unknown resistance. In the major barley states of Minnesota and North Dakota, percentages of reported acres with unknown resistance were generally low but were highest in the Southwest, West Central, and South Central districts of North Dakota $(12 \%)$ and the Northeast district of Minnesota (13\%).

Use of fungicides. Growers were asked several questions about their approach to managing FHB with fungicides, including how often they sprayed specifically to control FHB, whether they applied FHBtargeted fungicides themselves or hired custom applicators to apply by air or ground, and what sort of application technology they used.

States varied considerably, including within market-class regions, as to how many growers reported having applied an FHB-targeted fungicide, including custom applications, within the last 5 years (Table 5). The highest percentages of routine (every year) applications were found in Kentucky (41\%) and North Dakota (33\%). In those two states, only 21 and 35\%, respectively, had not applied an FHB-targeted fungicide in any of the previous 5 years; in the other 15 states, a majority of respondents had not done so. Apart from Kentucky, the percentage of growers in the soft wheat region who had applied an FHB-targeted fungicide at least once in the past 5 years ranged from a low of $26 \%$ in New York to a high of $49 \%$ in Illinois and Michigan.

In most states, the percentage who had hired a custom applicator for an FHB-targeted fungicide substantially exceeded the percentage who had applied a fungicide themselves for that purpose (Table 5). Across states, growers were about twice as likely to have hired a custom applicator $(31 \%)$ as to have applied an FHB-targeted fungicide themselves (15\%) (data not otherwise shown). Only about $7 \%$ reported having done both in the previous 5 years, and $60 \%$ reported neither.

Of those who had engaged a custom applicator, the 17-state mean percentages of aerial and ground application were similar (14 versus 17\%; Table 5). However, in some states more respondents reported contracting an aerial application (e.g., North Dakota, Nebraska,

Table 4. Barley area by level of Fusarium head blight (FHB) resistance reported by growers ${ }^{\mathrm{a}}$

\begin{tabular}{|c|c|c|c|c|c|c|c|c|c|c|c|c|}
\hline \multirow[b]{3}{*}{ State/region } & \multicolumn{8}{|c|}{ Level of FHB resistance ${ }^{b}$} & \multirow{2}{*}{\multicolumn{2}{|c|}{ Unknown cultivar ${ }^{\mathbf{c}}$}} & \multirow{2}{*}{\multicolumn{2}{|c|}{ Total }} \\
\hline & \multicolumn{2}{|c|}{ MR } & \multicolumn{2}{|c|}{ MS } & \multicolumn{2}{|l|}{$\mathbf{S}$} & \multicolumn{2}{|c|}{ Unknown resistance } & & & & \\
\hline & Hectarage & $\begin{array}{c}\text { Row total } \\
\text { hectarage } \\
(\%)\end{array}$ & Hectarage & $\begin{array}{c}\text { Row total } \\
\text { hectarage } \\
(\%)\end{array}$ & Hectarage & $\begin{array}{c}\text { Row total } \\
\text { hectarage } \\
(\%)\end{array}$ & Hectarage & $\begin{array}{c}\text { Row total } \\
\text { hectarage } \\
(\%)\end{array}$ & Hectarage & $\begin{array}{c}\text { Row total } \\
\text { hectarage } \\
(\%)\end{array}$ & Hectarage & $\begin{array}{c}\text { Table } \\
\text { hectarage } \\
(\%)\end{array}$ \\
\hline North Dakota & 1,717 & 3 & 26,002 & 53 & 17,628 & 36 & 1,952 & 4 & 2,197 & 4 & 49,497 & 72 \\
\hline Minnesota & $202-404$ & $3-6$ & 2,511 & 40 & 2,871 & 45 & $202-404$ & $3-6$ & 411 & 6 & 6,331 & 9 \\
\hline $\begin{array}{l}\text { Maryland, } \\
\text { North } \\
\text { Carolina, } \\
\text { Virginia, } \\
\text { Pennsylvania }\end{array}$ & 2,312 & 31 & $40-101$ & $\sim 1$ & $2,023-3,035$ & $27-41$ & 612 & 8 & 1,738 & 23 & 7,447 & 11 \\
\hline $\begin{array}{l}\text { Kansas, } \\
\text { Missouri, } \\
\text { Nebraska, } \\
\text { South } \\
\text { Dakota }\end{array}$ & 747 & 27 & 244 & 9 & $809-1,214$ & $29-43$ & $405-809$ & $14-29$ & 364 & 13 & 2,804 & 4 \\
\hline $\begin{array}{l}\text { Illinois, } \\
\text { Indiana, } \\
\text { Kentucky, } \\
\text { Michigan, } \\
\text { Ohio, } \\
\text { New York }\end{array}$ & $101-202$ & $5-9$ & $20-40$ & $1-2$ & 242 & 11 & 859 & 38 & 1,001 & 45 & 2,247 & 3 \\
\hline Total & 5,188 & 8 & 28,871 & 42 & 24,316 & 36 & 4,240 & 6 & 5,711 & 8 & 68,326 & \\
\hline
\end{tabular}

${ }^{a}$ Respondents were asked to name the three cultivars with the most planted area the last time barley was harvested for grain.

${ }^{\mathrm{b}} \mathrm{MR}=$ moderately resistant, $\mathrm{MS}=$ moderately susceptible, and $\mathrm{S}=$ susceptible. Unknown resistance indicates that the cultivar was not rated for FHB resistance

${ }^{\mathrm{c}}$ Unknown cultivar indicates that the cultivar was not identified as a result of problems with the respondent's recall or data entry. 
Arkansas, and Illinois), whereas in other states a strong majority had used a ground applicator (e.g., Michigan, Ohio, Kentucky, Virginia, Pennsylvania, and New York).

Growers were asked which fungicide they applied last time FHB was the primary target. The total number of responses was 5,191 , because some of the 5,107 farms reported more than one fungicide, and in such cases each fungicide was counted as a separate response (Table 6). In most responses (65\%), the grower did not name a fungicide; that percentage varied from a low of $29 \%$ in Kentucky to a high of $86 \%$ in Nebraska.

Overall, an estimated $10 \%$ of respondents named one of the recommended DMIs (metconazole, prothioconazole, and prothioconazole plus tebuconazole) (Table 6). Another 9\% named a less effective DMI or a QoI-containing product. States with relatively large percentages naming one of the most effective DMIs were North Dakota, Illinois, and Kentucky. Interestingly, Kentucky, along with South Dakota, also had a relatively large percentage of people naming QoI or QoI plus DMI mix products, which can elevate DON contamination from an FHB epidemic and are therefore not recommended for FHB management.

Whether growers named one of the recommended DMI products (or any fungicide) applied with FHB as the primary target was positively associated with the number of years (of the previous 5 years) that respondents had had DON problems, FHB-related dockage, or reduced yield attributable to FHB or with the sum of all three problems $(P<0.0001$ in all cases $)$. In other words, there was a significant

Table 5. Estimated percentages of growers reporting that fungicides were applied for Fusarium head blight (FHB) control on at least some of their wheat or barley crop ${ }^{\mathrm{a}}$

\begin{tabular}{|c|c|c|c|c|c|c|c|c|c|c|c|}
\hline \multirow[b]{3}{*}{ State } & \multirow{2}{*}{\multicolumn{7}{|c|}{ Years fungicides were applied in past 5 years $^{b}$}} & \multicolumn{4}{|c|}{ FHB-targeted fungicide applied ${ }^{c}$} \\
\hline & & & & & & & & \multirow[b]{2}{*}{ Self } & \multicolumn{2}{|c|}{ Custom applicator } & \multirow[b]{2}{*}{ Maximum SE } \\
\hline & $\mathbf{0}$ & 1 & 2 & 3 & 4 & 5 & Maximum SE & & Aerial & Ground & \\
\hline Kentucky & 21 & 10 & 11 & 12 & 4 & 41 & 4.3 & 35 & 5 & 44 & 4.4 \\
\hline North Dakota & 35 & 7 & 8 & 11 & 5 & 33 & 2.0 & 42 & 28 & 15 & 2.0 \\
\hline Michigan & 50 & 7 & 10 & 8 & 2 & 22 & 2.7 & 17 & 7 & 35 & 2.7 \\
\hline South Dakota & 51 & 10 & 8 & 10 & 2 & 18 & 2.8 & 18 & 21 & 17 & 2.3 \\
\hline Illinois & 51 & 14 & 11 & 10 & 4 & 10 & 3.0 & 10 & 32 & 15 & 2.8 \\
\hline Maryland & 52 & 13 & 7 & 7 & 3 & 16 & 3.4 & 19 & 15 & 24 & 3.1 \\
\hline North Carolina & 55 & 11 & 7 & 10 & 1 & 9 & 3.7 & 22 & 6 & 12 & 3.6 \\
\hline Indiana & 56 & 11 & 8 & 9 & 2 & 9 & 3.2 & 14 & 15 & 20 & 2.7 \\
\hline Ohio & 56 & 14 & 11 & 7 & 3 & 8 & 2.3 & 13 & 12 & 28 & 2.2 \\
\hline Minnesota & 64 & 6 & 5 & 4 & 3 & 15 & 2.7 & 19 & 14 & 7 & 2.5 \\
\hline Arkansas & 61 & 9 & 8 & 9 & - & 12 & 5.3 & 10 & 23 & 5 & 4.3 \\
\hline Virginia & 62 & 6 & 5 & 5 & 5 & 10 & 4.5 & 14 & 4 & 19 & 3.8 \\
\hline Missouri & 66 & 12 & 7 & 8 & 0 & 6 & 2.9 & 9 & 11 & 16 & 2.3 \\
\hline New York & 67 & 11 & 3 & 5 & 2 & 5 & 3.8 & 12 & 3 & 16 & 3.0 \\
\hline Pennsylvania & 69 & 5 & 4 & 7 & 3 & 8 & 2.4 & 13 & 2 & 17 & 2.0 \\
\hline Kansas & 76 & 7 & 4 & 8 & 0 & 3 & 2.2 & 5 & 9 & 5 & 1.5 \\
\hline Nebraska & 80 & 4 & 4 & 6 & 1 & 3 & 2.8 & 2 & 12 & 3 & 2.3 \\
\hline Total & 58 & 9 & 7 & 8 & 2 & 13 & 0.8 & 15 & 14 & 17 & 0.6 \\
\hline
\end{tabular}

a An unspecified response (no specific number of years) was recorded for between 0 and $7 \%$ of respondents in each state, with the overall average being $2 \%$. SE $=$ standard error of the estimates. No estimate provided where standard error could not be estimated as a result of the small sample.

b Specifically for FHB control, either by self or custom applicator.

c Years were 2009 to 2013 except in Kentucky, where they were 2010 to 2014.

Table 6. Fungicide applied most recently when Fusarium head blight (FHB) was the primary target by wheat and barley producers in 17 U.S. states ${ }^{\mathrm{a}}$

\begin{tabular}{|c|c|c|c|c|c|c|c|}
\hline State & Best DMI for FHB & Other DMI & DMI-QoI mix & QoI & None (no response) & Unusable $^{\mathbf{b}}$ & Maximum SE \\
\hline Arkansas & $-^{c}$ & 12 & 5 & 1 & 71 & 11 & 4.7 \\
\hline Nebraska & 1 & 0 & 4 & 4 & 86 & 4 & 2.4 \\
\hline Kansas & 3 & 3 & 3 & 1 & 83 & 7 & 1.9 \\
\hline North Carolina & 4 & 3 & 5 & 5 & 64 & 16 & 3.6 \\
\hline Missouri & 4 & 1 & 1 & 6 & 72 & 14 & 2.7 \\
\hline New York & 6 & 2 & 3 & 2 & 79 & 8 & 3.3 \\
\hline Pennsylvania & 7 & 2 & 2 & 2 & 75 & 12 & 2.2 \\
\hline Indiana & 8 & 1 & 2 & 4 & 63 & 21 & 3.2 \\
\hline Ohio & 12 & 1 & 2 & 2 & 64 & 19 & 2.2 \\
\hline Maryland & 12 & 3 & 6 & 2 & 62 & 15 & 3.2 \\
\hline Virginia & 12 & 3 & 0 & 2 & 70 & 11 & 4.0 \\
\hline South Dakota & 12 & 5 & 3 & 9 & 55 & 15 & 2.8 \\
\hline Michigan & 14 & 1 & 2 & 4 & 59 & 18 & 2.7 \\
\hline Minnesota & 14 & 8 & 1 & 4 & 66 & 6 & 2.5 \\
\hline Kentucky & 19 & 7 & 4 & 11 & 29 & 30 & 4.1 \\
\hline Illinois & 20 & 2 & 1 & 5 & 60 & 12 & 2.9 \\
\hline North Dakota & 24 & 10 & 2 & 7 & 42 & 15 & 2.0 \\
\hline Total & 10 & 3 & 2 & 4 & 65 & 14 & 0.7 \\
\hline
\end{tabular}

${ }^{a}$ Estimated percentages of producers are shown. Respondents were asked to name the fungicide applied the last time FHB was the primary target. Best demethylation inhibitor (DMI; triazole) for FHB = Prosaro, Caramba, or Proline; other DMI = a product containing propiconazole, tebuconazole, or a combination of the two; and QoI = quinone outside inhibitor (strobilurin). Not shown are seven responses of other fungicides that were not DMIs, QoIs, or a mixture of those. Also not shown are 14 responses of herbicides or insecticides. The total sample was 5,191 instead of 5,107 because a few respondents reported two or more fungicides.

${ }^{\mathrm{b}}$ Unusable indicates that the respondents made a response to the question, but it could not be interpreted.

c The dash indicates that the mean is not reported because the sample size was too small to calculate a SE. 
relationship between the experience of FHB problems and the frequency with which one of the most effective fungicides was named as having been applied, which is logical.

Growers named one of the most effective DMIs with higher frequency if they had applied an FHB-targeted fungicide themselves in the past 5 years and had not used a custom applicator (33\%), than the reverse (those who had relied exclusively on custom applicators and not made the application personally; 24\%). Interestingly, those who reported having both applied personally and engaged a custom

Table 7. Estimated percentages of wheat and barley growers with internet access in a national survey on Fusarium head blight management practices ${ }^{\mathrm{a}}$

\begin{tabular}{|c|c|c|c|c|c|}
\hline \multirow[b]{2}{*}{ State } & \multicolumn{2}{|c|}{$\begin{array}{c}\text { Had } \\
\text { internet } \\
\text { access }\end{array}$} & \multicolumn{2}{|c|}{$\begin{array}{c}\text { (If yes to previous } \\
\text { question) Had access to } \\
\text { a high-speed internet } \\
\text { connection }\end{array}$} & \multirow{2}{*}{$\underset{\text { SE }^{\mathbf{b}}}{\operatorname{Maximum}}$} \\
\hline & Yes & No & Yes & No & \\
\hline Pennsylvania & 46 & 49 & 36 & 7 & 2.6 \\
\hline Maryland & 58 & 38 & 47 & 9 & 3.5 \\
\hline New York & 59 & 37 & 49 & 7 & 3.6 \\
\hline Arkansas & 62 & 38 & 49 & 11 & 5.5 \\
\hline Virginia & 63 & 33 & 48 & 13 & 4.8 \\
\hline Michigan & 64 & 31 & 50 & 12 & 2.9 \\
\hline Missouri & 64 & 34 & 51 & 13 & 3.1 \\
\hline Ohio & 68 & 28 & 53 & 12 & 2.4 \\
\hline Illinois & 69 & 28 & 54 & 15 & 3.1 \\
\hline North Carolina & 69 & 29 & 59 & 9 & 4.1 \\
\hline Indiana & 73 & 24 & 61 & 10 & 3.2 \\
\hline Kansas & 73 & 22 & 61 & 11 & 2.5 \\
\hline Nebraska & 73 & 23 & 61 & 11 & 3.4 \\
\hline Kentucky & 74 & 22 & 64 & 10 & 4.3 \\
\hline Minnesota & 76 & 20 & 65 & 10 & 3.1 \\
\hline South Dakota & 76 & 22 & 67 & 8 & 2.6 \\
\hline North Dakota & 82 & 17 & 73 & 7 & 1.9 \\
\hline Total & 69 & 27 & 57 & 11 & 0.8 \\
\hline
\end{tabular}

${ }^{a}$ On internet access, nonspecific responses ranged from 1 to $6 \%$ in each state, with an overall average of $4 \%$. On high-speed connection, 1,564 did not respond and 80 provided a nonspecific response.

b $\mathrm{SE}=$ standard error of the estimates. applicator for FHB in the past 5 years named one of the most effective DMIs with the highest frequency of $41 \%$. All three percentages differed significantly $(P<0.05)$.

FHB information sources. Internet access varied by state and region of the country (Table 7). States with the lowest reported percentage of access were in the Northeast (Pennsylvania, Maryland, and New York), whereas states with the highest percentage were in the upper Midwest (North Dakota, South Dakota, and Minnesota). Depending on the state, access to high-speed internet was between 9 and 15 percentage points lower than internet access (mean of $12 \%$ lower).

Overall, crop consultants were considered by the largest percentage of growers to be an important source or their primary source of information on risk or management of FHB (Table 8). The percentage of growers who indicated crop consultants were their primary source of information was highest (40 to $45 \%$ ) in Illinois, North Dakota, and Ohio and lowest (14 to 24\%) in Missouri, Nebraska, North Carolina, and Virginia. Reliance upon FHB information from an extension/ university source varied considerably among states, with relatively high percentages (22 to 30\%) considering this their primary source in Arkansas, Kentucky, Nebraska, North Carolina, and North Dakota, and relatively low percentages (5 to $11 \%$ ) in Illinois, Indiana, Maryland, and Michigan. Regarding important sources of information, there was no positive or negative association between consultants and extension/university; use of one did not appear to affect use of the other. The survey did not address the degree to which consultants obtained their FHB information from extension and university sources.

Chemical companies and other farmers were cited as the primary source of information by 11 and $13 \%$ of all respondents, respectively (Table 8). Those who selected chemical companies as an important source of information also tended to indicate consultants. Grain buyers were the least relied-upon source, with $3 \%$ overall naming them as the primary source. Finally, $24 \%$ of respondents did not indicate a primary source for FHB-related information, with a large range among states (14 to $35 \%$ ).

Print publications were selected by the largest percentages of respondents as either a utilized source $(42 \%)$ or their primary method (37\%) of receiving information on risk or management of FHB (Table 9). By state, the range for primary method was from $28 \%$ (Minnesota and Virginia) to $51 \%$ (Kentucky). Social media had a low percentage ( 2 to $3 \%$ overall), whereas e-mail alerts and alerts

Table 8. Estimated percentages of U.S. wheat and barley growers in 17 states who use particular entities as either an important source or their primary source for obtaining information on risk or management of Fusarium head blight ${ }^{\mathrm{a}}$

\begin{tabular}{|c|c|c|c|c|c|c|c|c|c|c|c|c|c|}
\hline \multirow[b]{2}{*}{ State } & \multicolumn{2}{|c|}{$\begin{array}{l}\text { Extension/ } \\
\text { university }\end{array}$} & \multicolumn{2}{|c|}{$\begin{array}{c}\text { Crop } \\
\text { consultants }\end{array}$} & \multicolumn{2}{|c|}{$\begin{array}{c}\text { Chemical } \\
\text { companies }\end{array}$} & \multicolumn{2}{|c|}{ Grain buyers } & \multicolumn{2}{|c|}{$\begin{array}{c}\text { Other } \\
\text { farmers }\end{array}$} & \multicolumn{2}{|c|}{ No response } & \multirow[b]{2}{*}{ Maximum $\mathrm{SE}^{\mathrm{b}}$} \\
\hline & Imp & Prim & $\operatorname{Imp}$ & Prim & $\operatorname{Imp}$ & Prim & $\operatorname{Imp}$ & Prim & Imp & Prim & Imp & Prim & \\
\hline Arkansas & 36 & 23 & 37 & 31 & 23 & 14 & 3 & - & 12 & 6 & 25 & 26 & 5.4 \\
\hline Illinois & 18 & 5 & 51 & 45 & 27 & 17 & 9 & 5 & 26 & 14 & 12 & 14 & 3.1 \\
\hline Indiana & 22 & 7 & 48 & 39 & 28 & 17 & 8 & 2 & 22 & 11 & 21 & 25 & 3.3 \\
\hline Kansas & 27 & 17 & 33 & 26 & 12 & 6 & 6 & 2 & 25 & 14 & 32 & 35 & 2.4 \\
\hline Kentucky & 36 & 23 & 43 & 28 & 31 & 18 & 9 & 2 & 31 & 12 & 13 & 17 & 4.4 \\
\hline Maryland & 28 & 11 & 50 & 40 & 20 & 9 & 5 & 1 & 22 & 8 & 29 & 31 & 3.5 \\
\hline Michigan & 23 & 9 & 45 & 37 & 20 & 9 & 12 & 5 & 29 & 15 & 20 & 24 & 2.8 \\
\hline Minnesota & 26 & 14 & 37 & 28 & 18 & 4 & 8 & 5 & 25 & 13 & 38 & 35 & 3.0 \\
\hline Missouri & 26 & 14 & 32 & 24 & 18 & 10 & 10 & 4 & 38 & 23 & 21 & 25 & 3.0 \\
\hline Nebraska & 31 & 23 & 33 & 23 & 16 & 7 & 4 & 0 & 29 & 20 & 26 & 27 & 3.3 \\
\hline New York & 37 & 19 & 48 & 34 & 15 & 2 & 7 & 3 & 26 & 11 & 27 & 30 & 3.8 \\
\hline North Carolina & 41 & 30 & 23 & 14 & 26 & 16 & 7 & 4 & 18 & 7 & 31 & 29 & 3.8 \\
\hline North Dakota & 42 & 22 & 51 & 39 & 31 & 14 & 8 & 2 & 29 & 8 & 12 & 15 & 2.1 \\
\hline Ohio & 24 & 13 & 47 & 40 & 22 & 11 & 8 & 4 & 29 & 12 & 18 & 21 & 2.5 \\
\hline Pennsylvania & 24 & 12 & 41 & 32 & 22 & 12 & 10 & 4 & 26 & 14 & 30 & 26 & 2.5 \\
\hline South Dakota & 27 & 13 & 46 & 39 & 23 & 11 & 10 & 5 & 29 & 13 & 18 & 20 & 2.9 \\
\hline Virginia & 30 & 16 & 30 & 22 & 22 & 21 & 5 & 2 & 24 & 10 & 32 & 30 & 4.2 \\
\hline Total & 28 & 16 & 41 & 32 & 22 & 11 & 8 & 3 & 27 & 13 & 23 & 24 & 0.8 \\
\hline
\end{tabular}

a For "important source" (Imp), respondents could select all that applied, whereas for "primary source" (Prim), they were asked to select one. The dash indicates the sample size was too small to calculate a standard error.

${ }^{\mathrm{b}} \mathrm{SE}=$ maximum standard error of the estimate. 
by cell phone were 7 to $11 \%$. A large percentage (45\%) reported no method or technology of acquiring FHB information.

Predictably, use of texts or e-mails on a cell phone to obtain information on risk or management of FHB was correlated with access to the internet. By itself, e-mail as an information source was associated with internet access. Internet access was positively associated with higher levels of formal education and negatively associated with years operating a farm.

Overall, $6 \%$ of the 5,107 growers said they had used a risk forecasting website as a source of FHB information during the past 5 years (Table 9). A check on direct risk forecast use as shown in Table 9 was possible because a separate question in the survey asked only whether respondents had used a website that forecasts FHB risk in the last 5 years. For each state, there was a difference of $\leq 5 \%$ in positive responses; in most states, the two differed by 0 to 2 percentage points. The overall average for forecasting site use was 5 to $6 \%$ in both formulations of the question. The percentage who said they had used a risk forecasting site was higher in North Dakota (14 to $16 \%$, depending on wording of the question) than in any other state.

Factors associated with MR cultivar adoption. Various factors were evaluated for potential association with adoption of moderate cultivar resistance, with adoption measured by growers' reporting of the top three cultivars and area of each planted the last time wheat or barley was grown for grain.

Demographic factors and operation size. For SRW wheat, none of the demographic or operation-size factors were associated with greater reported usage of MR cultivars (Table 10). A few of these predictors were associated with increased naming of MR cultivars for each of the other market classes, however. For example, higher levels of education were associated with increased MR use for HRS and HRW. Larger farm size was associated with increased MR use for durum and HRW growers, and more small grain hectares was associated with increased MR use for HRW growers. Interestingly, the trends were opposite for barley: those with smaller farms and fewer hectares of the top three varieties had the larger percentage of MR hectares (Table 10). In addition, growers with fewer years of education reported a larger percentage of MR hectares.

Because these trends were surprising, the data set was separated into barley growers in the top two barley states, North Dakota and Minnesota, versus all other states. This division was explored because North Dakota and Minnesota had a similar distribution of
MR-MS-S percentages (Table 4) and together constitute a different and much larger barley production region. It turned out that in Minnesota and North Dakota, larger farms tended to have higher MR adoption, but those that reported the largest acreage of their top three barley cultivars tended to have lower MR adoption. For the other states, larger farms tended to have lower MR adoption, but those with relatively large barley acreage tended to have higher MR adoption. With respect to education, there was no association between lower levels of education and greater adoption of MR barley cultivars among Minnesota and North Dakota growers. However, there was such an association in the other states, taken together: those with a high school diploma or less reported a higher percentage of MR barley area than those with a college degree.

Spending $50 \%$ or more time on the farm was associated with greater MR cultivar use for HRW and SWW growers, but not for those of other market classes. Only for durum growers was there an association between more years in farming (up to 50 years) and greater MR use. Higher yields were associated with greater MR use only for HRS and SWW growers. Trends in tillage varied among market classes, with greater MR use associated with low or minimum tillage for HRS and HRW growers.

Information access and consumption. Internet access was strongly associated with greater use of MR cultivars only for SWW growers (Table 10). Surprisingly, barley growers reported greater use of MR cultivars if they lacked internet access than if they had it. With respect to source of FHB information, primary reliance on extension and university sources was associated with greater MR cultivar use for all wheat market classes except SWW. By contrast, barley growers reported more MR hectares if they relied on chemical companies or crop consultants for FHB information. Technology for receiving FHB information showed no clear trends; MR planting was greater for barley growers who relied on print and cell phone notifications, whereas it was greater for durum growers who relied on the risk forecasting website and HRW growers who relied on cell phone notifications.

History of FHB problems. These predictors were not strongly associated with increased MR usage (Table 10). There was no trend for more years of previous FHB problems to be associated with greater MR cultivar use. Only for HRS was the experience of FHB reducing yield at least 1 of the past 5 years associated with a higher reported frequency of MR hectares.

Use of management practices. Growers were asked to indicate which of the following management practices they used for FHB:

Table 9. Estimated percentages of U.S. wheat and barley growers in 17 states who use various technologies as either a method or their primary method for obtaining information on risk or management of Fusarium head blight ${ }^{\mathrm{a}}$

\begin{tabular}{|c|c|c|c|c|c|c|c|c|c|c|c|c|c|}
\hline \multirow[b]{2}{*}{ State } & \multicolumn{2}{|c|}{ E-mail alerts } & \multicolumn{2}{|c|}{ Print publications } & \multicolumn{2}{|c|}{$\begin{array}{c}\text { Risk forecasting } \\
\text { website }\end{array}$} & \multicolumn{2}{|c|}{$\begin{array}{c}\text { Social media } \\
\text { (Facebook, Twitter) }\end{array}$} & \multicolumn{2}{|c|}{$\begin{array}{l}\text { Texts or e-mails on } \\
\text { cell phone }\end{array}$} & \multicolumn{2}{|c|}{ None reported } & \multirow[b]{2}{*}{$\underset{\mathbf{S E}^{\mathbf{b}}}{\operatorname{Maximum}}$} \\
\hline & $\begin{array}{c}\text { A } \\
\text { method }\end{array}$ & $\begin{array}{l}\text { Primary } \\
\text { method }\end{array}$ & $\begin{array}{c}\text { A } \\
\text { method }\end{array}$ & $\begin{array}{c}\text { Primary } \\
\text { method }\end{array}$ & $\begin{array}{c}\text { A } \\
\text { method }\end{array}$ & $\begin{array}{l}\text { Primary } \\
\text { method }\end{array}$ & $\begin{array}{c}\text { A } \\
\text { method }\end{array}$ & $\begin{array}{l}\text { Primary } \\
\text { method }\end{array}$ & $\begin{array}{c}\text { A } \\
\text { method }\end{array}$ & $\begin{array}{l}\text { Primary } \\
\text { method }\end{array}$ & $\begin{array}{c}\text { A } \\
\text { method }\end{array}$ & $\begin{array}{l}\text { Primary } \\
\text { method }\end{array}$ & \\
\hline Arkansas & 15 & 12 & 35 & 31 & 3 & 3 & 6 & 5 & 12 & 5 & 49 & 44 & 5.6 \\
\hline Illinois & 12 & 7 & 44 & 40 & 5 & 3 & 4 & 2 & 16 & 11 & 36 & 37 & 3.1 \\
\hline Indiana & 11 & 8 & 39 & 34 & 4 & 2 & 2 & 1 & 10 & 7 & 47 & 47 & 3.3 \\
\hline Kansas & 8 & 5 & 39 & 36 & 4 & 1 & 3 & 2 & 6 & 4 & 50 & 52 & 2.6 \\
\hline Kentucky & 13 & 9 & 56 & 51 & 6 & 3 & 4 & 1 & 11 & 5 & 29 & 32 & 4.4 \\
\hline Maryland & 10 & 4 & 35 & 31 & 6 & 4 & 0 & 0 & 6 & 5 & 60 & 56 & 3.5 \\
\hline Michigan & 12 & 7 & 38 & 34 & 4 & 2 & 2 & 1 & 10 & 7 & 47 & 49 & 2.9 \\
\hline Minnesota & 12 & 5 & 37 & 28 & 8 & 4 & 2 & 1 & 11 & 8 & 56 & 54 & 3.2 \\
\hline Missouri & 11 & 7 & 45 & 43 & 5 & 3 & 3 & 2 & 12 & 8 & 38 & 38 & 3.1 \\
\hline Nebraska & 11 & 6 & 43 & 40 & 4 & 3 & 2 & 1 & 7 & 7 & 43 & 43 & 3.5 \\
\hline New York & 14 & 7 & 41 & 31 & 5 & 3 & 1 & - & 8 & 4 & 49 & 54 & 4.0 \\
\hline $\begin{array}{l}\text { North } \\
\text { Carolina }\end{array}$ & 13 & 8 & 43 & 37 & 3 & 2 & 2 & 1 & 12 & 8 & 52 & 45 & 3.8 \\
\hline North Dakota & 17 & 10 & 43 & 33 & 14 & 9 & 6 & 3 & 13 & 8 & 35 & 36 & 2.1 \\
\hline Ohio & 13 & 7 & 42 & 37 & 9 & 5 & 3 & 1 & 11 & 7 & 40 & 42 & 2.4 \\
\hline Pennsylvania & 5 & 3 & 45 & 41 & 2 & 2 & 3 & 2 & 4 & 3 & 54 & 50 & 2.6 \\
\hline South Dakota & 7 & 4 & 43 & 39 & 6 & 2 & 3 & 2 & 12 & 11 & 41 & 42 & 2.8 \\
\hline Virginia & 10 & 5 & 34 & 28 & 4 & 1 & 1 & 1 & 7 & 4 & 64 & 61 & 4.7 \\
\hline Total & 11 & 7 & 42 & 37 & 6 & 3 & 3 & 2 & 10 & 7 & 44 & 44 & 0.8 \\
\hline
\end{tabular}

a For "a method," respondents could select all that applied, whereas for "primary method," they were asked to select one. Means are not reported where sample sizes were too small to calculate a standard error.

b Standard error of the estimates. 
Table 10. Estimated percentage of moderately resistant (MR) crop area grown by producers in 17 states, shown by barley or wheat market class and by demographic and Fusarium head blight (FHB) history factors ${ }^{\mathrm{a}}$

\begin{tabular}{|c|c|c|c|c|c|c|c|c|c|c|c|c|}
\hline \multirow[b]{3}{*}{ Factor } & \multirow{2}{*}{\multicolumn{2}{|c|}{ Barley }} & \multicolumn{10}{|c|}{ Wheat } \\
\hline & & & \multicolumn{2}{|c|}{ Durum } & \multicolumn{2}{|c|}{ Hard red spring } & \multicolumn{2}{|c|}{ Hard red winter } & \multicolumn{2}{|c|}{ Soft red winter } & \multicolumn{2}{|c|}{ Soft white winter } \\
\hline & Hectarage & $\%$ & Hectarage & $\%$ & Hectarage & $\%$ & Hectarage & $\%$ & Hectarage & $\%$ & Hectarage & $\%$ \\
\hline \multicolumn{13}{|l|}{$\begin{array}{l}\text { Demographic factors, operation } \\
\text { size, and practices }\end{array}$} \\
\hline \multicolumn{13}{|l|}{ Education received } \\
\hline College degree & & 12.4 & & 19.7 & & 46.2 & & 8.2 & & 12.9 & & 13.1 \\
\hline Some college & & 7.4 & & 37.0 & & 50.9 & & 5.7 & & 14.6 & & 10.7 \\
\hline High school diploma & & 24.4 & & 16.2 & & 41.0 & & 6.9 & & 17.4 & & 7.7 \\
\hline No high school diploma & & 34.8 & & - & & 26.0 & & 3.9 & & 20.6 & & - \\
\hline Maximum SE & & 3.8 & & 6.0 & & 7.9 & & 2.0 & & 4.8 & & 3.7 \\
\hline \multicolumn{13}{|l|}{$\begin{array}{l}\text { Farm size (hectarage owned } \\
\text { and rented) }\end{array}$} \\
\hline$>607$ (>1,500 acres) & & 9.7 & & 35.0 & & 48.6 & & 11.1 & & 20.1 & & 19.9 \\
\hline 284-607 (701-1,500 acres) & & 14.4 & & 24.3 & & 50.7 & & 7.1 & & 14.7 & & 6.9 \\
\hline $122-283$ (301-700 acres) & & 23.9 & & 6.6 & & 42.5 & & 5.7 & & 15.3 & & 7.6 \\
\hline $0-121$ (0-300 acres) & & 27.0 & & 15.6 & & 37.4 & & 3.2 & & 15.6 & & 9.6 \\
\hline Maximum SE & & 2.7 & & 13.0 & & 5.1 & & 1.2 & & 2.6 & & 5.8 \\
\hline \multicolumn{13}{|l|}{$\begin{array}{l}\text { Hectarage grown (top three } \\
\text { cultivars) }\end{array}$} \\
\hline & $\geq 122$ & 3.4 & $\geq 122$ & 32.2 & $\geq 163$ & 49.3 & $\geq 122$ & 6.6 & $\geq 81$ & 14.9 & $\geq 81$ & 15.9 \\
\hline & $62-121$ & 11.4 & $0.4-121$ & 21.3 & $82-162$ & 45.5 & $42-121$ & 10.2 & $42-81$ & 14.9 & $21-81$ & 7.6 \\
\hline & $21-61$ & 19.2 & & & $42-81$ & 47.1 & $13-41$ & 6.3 & $21-41$ & 15.9 & $0.4-20$ & 7.8 \\
\hline & $0.4-20$ & 25.1 & & & $0.4-41$ & 38.7 & $0.4-12$ & 2.9 & $0.4-20$ & 15.8 & & \\
\hline Maximum SE & & 2.4 & & 4.5 & & 3.9 & & 1.5 & & 2.0 & & 3.3 \\
\hline \multicolumn{13}{|l|}{ Spend $\geq 50 \%$ time on farm } \\
\hline Yes & & 19.4 & & 26.6 & & 45.9 & & 7.0 & & 16.0 & & 10.0 \\
\hline No & & 14.2 & & 29.1 & & 46.0 & & 3.3 & & 13.1 & & 3.1 \\
\hline Maximum SE & & 4.0 & & 14.3 & & 5.8 & & 1.0 & & 2.2 & & 1.7 \\
\hline \multicolumn{13}{|l|}{ Years farming } \\
\hline $1-10$ & & 26.6 & & 4.0 & & 52.0 & & 5.8 & & 9.0 & & 32.1 \\
\hline $11-20$ & & 18.4 & & 28.5 & & 44.0 & & 7.7 & & 12.0 & & 9.2 \\
\hline $21-30$ & & 24.2 & & 41.9 & & 42.6 & & 5.0 & & 19.0 & & 2.6 \\
\hline $31-40$ & & 17.9 & & 31.5 & & 50.3 & & 8.1 & & 16.6 & & 11.3 \\
\hline $41-50$ & & 14.8 & & 37.9 & & 47.2 & & 4.8 & & 17.6 & & 5.9 \\
\hline$\geq 51$ & & 14.3 & & 8.3 & & 35.7 & & 7.8 & & 14.8 & & 11.9 \\
\hline Maximum SE & & 5.0 & & 9.0 & & 6.2 & & 1.9 & & 3.8 & & 19.2 \\
\hline \multicolumn{13}{|l|}{ Tillage prior to small grain crop } \\
\hline No till & & 17.6 & & 31.0 & & 37.2 & & 8.8 & & 13.0 & & 9.8 \\
\hline Minimum tillage & & 15.9 & & 22.3 & & 51.6 & & 5.2 & & 17.2 & & 8.7 \\
\hline Complete tillage & & 10.1 & & 19.8 & & 47.9 & & 5.0 & & 19.6 & & 7.1 \\
\hline Maximum SE & & 2.8 & & 12.2 & & 4.0 & & 1.2 & & 3.3 & & 2.6 \\
\hline \multicolumn{13}{|l|}{$\begin{array}{l}\text { Yield of most recent small } \\
\text { grain crop }\end{array}$} \\
\hline High & & 19.5 & & 24.6 & & 53.3 & & 3.6 & & 13.6 & & 12.8 \\
\hline Medium & & 19.5 & & 27.1 & & 48.9 & & 7.6 & & 16.4 & & 4.4 \\
\hline Low & & 16.6 & & 27.1 & & 32.0 & & 6.1 & & 20.8 & & 5.0 \\
\hline Maximum SE & & 2.9 & & 10.1 & & 3.7 & & 1.0 & & 4.0 & & 4.2 \\
\hline \multicolumn{13}{|l|}{$\begin{array}{l}\text { Information access and } \\
\text { consumption }\end{array}$} \\
\hline \multicolumn{13}{|l|}{ Access to internet } \\
\hline Yes & & 16.2 & & 30.2 & & 46.3 & & 7.1 & & 16.4 & & 11.2 \\
\hline No & & 25.0 & & 12.6 & & 44.1 & & 4.8 & & 13.6 & & 2.9 \\
\hline Maximum SE & & 2.2 & & 5.9 & & 3.8 & & 0.9 & & 1.5 & & 2.0 \\
\hline & & & & & & & & & & (Cont & nued on next & page) \\
\hline
\end{tabular}

a Table entries are estimated percentages of MR hectares among the three top varieties named by respondents when they had most recently planted that market class. Market classes are as follows: BAR $=$ barley, DUR $=$ durum wheat, HRS $=$ hard red spring wheat, HRW $=$ hard red winter wheat, SRW $=$ soft red winter wheat, and SWW = soft white winter wheat. SE = maximum standard errors of the estimates (estimates are not reported where sample sizes were too small to calculate a standard error).

${ }^{\mathrm{b}}$ In the barley column, values are for the most recent barley crop; in wheat columns, values are for the most recent wheat crop. High: wheat $=\geq 901 \mathrm{~kg} \mathrm{~m}^{-3}$ ( $\geq 70$ bu ac $\left.{ }^{-1}\right)$ and barley $=\geq 1,287 \mathrm{~kg} \mathrm{~m}^{-3}\left(\geq 100 \mathrm{bu} \mathrm{ac}^{-1}\right)$; medium: wheat $=515$ to $888 \mathrm{~kg} \mathrm{~m}^{-3}\left(40\right.$ to $\left.69 \mathrm{bu} \mathrm{ac}^{-1}\right)$ and barley $=644$ to $1,274 \mathrm{~kg} \mathrm{~m}^{-3}\left(50\right.$ to $\left.99 \mathrm{bu} \mathrm{ac}^{-1}\right)$; and low: wheat $=0$ to $502 \mathrm{~kg} \mathrm{~m}^{-3}\left(0\right.$ to $\left.39 \mathrm{bu} \mathrm{ac}^{-1}\right)$ and barley $=0$ to $631 \mathrm{~kg} \mathrm{~m}^{-3}$ (0 to $\left.49 \mathrm{bu} \mathrm{ac}^{-1}\right)$.

${ }^{\mathrm{c}}$ Maximum indicates the highest number of years reported for any of the following: in the past 5 years, how many years has FHB reduced yields, caused a deoxynivalenol (DON) problem, or caused dockage or load rejection? Sum indicates the total years in all three responses. Years were 2009 to 2013 except in Kentucky, where they were 2010 to 2014.

d Respondents could choose as many practices as applied; in the case of "grow MR cultivars," the percentages in the table (which are from specific cultivar hectarage reported elsewhere in the questionnaire) provide a cross-check with claimed use of the practice. Similarly, recommended fungicides reported here could be cross-checked with specific fungicides used as reported in Table 6. 
Table 10. (Continued from previous page)

\begin{tabular}{|c|c|c|c|c|c|c|c|c|c|c|c|c|}
\hline \multirow[b]{3}{*}{ Factor } & & & \multicolumn{10}{|c|}{ Wheat } \\
\hline & \multicolumn{2}{|c|}{ Barley } & \multicolumn{2}{|c|}{ Durum } & \multicolumn{2}{|c|}{ Hard red spring } & \multicolumn{2}{|c|}{ Hard red winter } & \multicolumn{2}{|c|}{ Soft red winter } & \multicolumn{2}{|c|}{ Soft white winter } \\
\hline & Hectarage & $\%$ & Hectarage & $\%$ & Hectarage & $\%$ & Hectarage & $\%$ & Hectarage & $\%$ & Hectarage & $\%$ \\
\hline \multicolumn{13}{|l|}{ Access to high-speed internet } \\
\hline Yes & & 15.2 & & 31.0 & & 45.2 & & 7.2 & & 16.4 & & 9.5 \\
\hline No & & 24.5 & & 18.6 & & 47.8 & & 5.4 & & 14.3 & & 7.4 \\
\hline Maximum SE & & 1.9 & & 5.2 & & 3.1 & & 0.8 & & 1.3 & & 2.1 \\
\hline \multicolumn{13}{|l|}{$\begin{array}{l}\text { Primary source of FHB } \\
\text { information }\end{array}$} \\
\hline Extension/university & & 11.5 & & 32.2 & & 50.0 & & 11.0 & & 22.0 & & 3.3 \\
\hline Chemical companies & & 27.9 & & 20.5 & & 44.1 & & 6.4 & & 13.6 & & 18.3 \\
\hline Crop consultants & & 20.2 & & 25.8 & & 49.8 & & 7.4 & & 12.4 & & 8.5 \\
\hline Grain buyers & & 3.7 & & 40.5 & & 53.5 & & 1.0 & & 21.5 & & 6.3 \\
\hline Other farmers & & 22.2 & & 5.0 & & 42.7 & & 3.7 & & 18.3 & & 10.0 \\
\hline Maximum SE & & 3.9 & & 22.1 & & 9.5 & & 1.6 & & 5.4 & & 7.6 \\
\hline \multicolumn{13}{|l|}{$\begin{array}{l}\text { Primary technology for FHB } \\
\text { information }\end{array}$} \\
\hline Social media & & 9.3 & & - & & 51.2 & & 2.1 & & 30.2 & & - \\
\hline Risk forecasting site & & 6.2 & & 47.6 & & 56.1 & & 9.5 & & 17.3 & & 13.2 \\
\hline Print publications & & 20.4 & & 18.4 & & 46.2 & & 7.4 & & 15.5 & & 8.9 \\
\hline E-mail alerts & & 15.0 & & 25.5 & & 55.2 & & 8.6 & & 12.6 & & 19.2 \\
\hline Text/e-mail to cell phone & & 22.2 & & 4.0 & & 47.4 & & 12.6 & & 10.9 & & 18.0 \\
\hline Maximum SE & & 6.1 & & 10.0 & & 9.5 & & 2.8 & & 10.5 & & 9.7 \\
\hline \multicolumn{13}{|l|}{ History of FHB problems } \\
\hline \multicolumn{13}{|l|}{$\begin{array}{l}\text { Maximum FHB problem } \\
\text { years }^{c}\end{array}$} \\
\hline 5 & & 19.0 & & 48.4 & & 53.7 & & 4.5 & & 15.4 & & 11.2 \\
\hline 4 & & 4.8 & & 36.0 & & 48.9 & & 10.4 & & 14.0 & & 19.0 \\
\hline 3 & & 9.0 & & 53.1 & & 61.1 & & 7.1 & & 13.6 & & 9.8 \\
\hline 2 & & 18.6 & & 18.1 & & 44.6 & & 12.1 & & 23.1 & & 4.8 \\
\hline 1 & & 18.8 & & 29.0 & & 53.9 & & 9.5 & & 12.9 & & 6.4 \\
\hline 0 & & 20.0 & & 22.3 & & 43.3 & & 5.7 & & 14.9 & & 8.8 \\
\hline Maximum SE & & 4.4 & & 19.1 & & 9.7 & & 5.2 & & 4.3 & & 13.0 \\
\hline Sum of FHB problem years ${ }^{c}$ & & & & & & & & & & & & \\
\hline$\geq 7$ & & 13.0 & & 43.7 & & 56.7 & & 7.2 & & 8.8 & & 9.2 \\
\hline $5-6$ & & 24.3 & & 64.8 & & 56.5 & & 10.8 & & 15.1 & & 11.4 \\
\hline $3-4$ & & 12.0 & & 19.4 & & 45.6 & & 3.2 & & 18.6 & & 6.6 \\
\hline $0-2$ & & 19.6 & & 22.5 & & 44.9 & & 6.6 & & 15.3 & & 8.4 \\
\hline Maximum SE & & 5.2 & & 14.5 & & 6.2 & & 3.5 & & 3.2 & & 6.0 \\
\hline $\begin{array}{l}\text { FHB reduced yield (years ou } \\
\text { of past } 5 \text { years) }\end{array}$ & & & & & & & & & & & & \\
\hline $1-5$ & & 15.6 & & 37.7 & & 52.1 & & 9.3 & & 16.2 & & 7.8 \\
\hline 0 & & 20.4 & & 19.4 & & 43.4 & & 5.9 & & 15.1 & & 8.9 \\
\hline Maximum SE & & 2.0 & & 5.5 & & 2.6 & & 1.4 & & 1.4 & & 2.0 \\
\hline $\begin{array}{l}\text { FHB has caused a DON pro } \\
\text { (years out of past } 5 \text { years) }\end{array}$ & & & & & & & & & & & & \\
\hline $1-5$ & & 18.1 & & 38.5 & & 49.5 & & 7.9 & & 14.0 & & 8.3 \\
\hline 0 & & 19.2 & & 21.4 & & 45.2 & & 6.3 & & 15.9 & & 8.7 \\
\hline Maximum SE & & 2.5 & & 6.3 & & 3.2 & & 1.7 & & 1.7 & & 2.1 \\
\hline $\begin{array}{r}\text { FHB has resulted in dockage } \\
\text { (years out of past } 5 \text { years) }\end{array}$ & & & & & & & & & & & & \\
\hline $1-5$ & & 20.1 & & 42.0 & & 53.4 & & 5.3 & & 15.0 & & 4.5 \\
\hline 0 & & 18.8 & & 23.1 & & 44.7 & & 6.6 & & 15.7 & & 9.6 \\
\hline Maximum SE & & 3.0 & & 7.3 & & 3.7 & & 1.3 & & 1.8 & & 2.1 \\
\hline $\begin{array}{l}\text { Use of FHB management } \\
\text { practices }\end{array}$ & & & & & & & & & & & & \\
\hline $\begin{array}{l}\text { Used FHB forecasting webs } \\
\text { (in past } 5 \text { years) }\end{array}$ & & & & & & & & & & & & \\
\hline Yes & & 6.1 & & 30.9 & & 52.7 & & 10.3 & & 12.7 & & 17.6 \\
\hline No & & 20.5 & & 25.9 & & 44.7 & & 6.3 & & 15.7 & & 7.8 \\
\hline Maximum SE & & 1.6 & & 7.9 & & 3.7 & & 2.5 & & 2.7 & & 7.3 \\
\hline $\begin{array}{l}\text { Practices used to reduce FHI } \\
\text { damage }^{\mathrm{d}}\end{array}$ & & & & & & & & & & & & \\
\hline Grow MR cultivars & & & & & & & & & & & & \\
\hline Yes & & 16.2 & & 29.0 & & 51.5 & & 7.8 & & 14.9 & & 9.4 \\
\hline No & & 21.9 & & 23.7 & & 36.8 & & 5.5 & & 16.4 & & 8.0 \\
\hline Maximum SE & & 1.6 & & 4.8 & & 2.4 & & 0.9 & & 1.3 & & 2.4 \\
\hline & & & & & & & & & & (Cont & nиed on nехt & page) \\
\hline
\end{tabular}




\begin{tabular}{|c|c|c|c|c|c|c|c|c|c|c|c|c|}
\hline \multirow[b]{3}{*}{ Factor } & \multirow{2}{*}{\multicolumn{2}{|c|}{ Barley }} & \multicolumn{10}{|c|}{ Wheat } \\
\hline & & & \multicolumn{2}{|c|}{ Durum } & \multicolumn{2}{|c|}{ Hard red spring } & \multicolumn{2}{|c|}{ Hard red winter } & \multicolumn{2}{|c|}{ Soft red winter } & \multicolumn{2}{|c|}{ Soft white winter } \\
\hline & Hectarage & $\%$ & Hectarage & $\%$ & Hectarage & $\%$ & Hectarage & $\%$ & Hectarage & $\%$ & Hectarage & $\%$ \\
\hline \multicolumn{13}{|c|}{$\begin{array}{l}\text { Apply a recommended } \\
\text { fungicide with FHB } \\
\text { as primary target }\end{array}$} \\
\hline Yes & & 12.2 & & 26.6 & & 52.2 & & 4.8 & & 15.9 & & 15.0 \\
\hline No & & 21.6 & & 26.9 & & 42.5 & & 6.8 & & 15.3 & & 4.0 \\
\hline Maximum SE & & 1.8 & & 5.1 & & 2.5 & & 1.0 & & 1.5 & & 2.8 \\
\hline \multicolumn{13}{|c|}{$\begin{array}{l}\text { Rotate; never/rarely } \\
\text { grow wheat after } \\
\text { small grains or corn }\end{array}$} \\
\hline Yes & & 14.6 & & 28.8 & & 50.0 & & 7.6 & & 17.1 & & 10.6 \\
\hline No & & 22.6 & & 25.0 & & 41.0 & & 5.8 & & 14.1 & & 6.6 \\
\hline Maximum SE & & 1.6 & & 4.7 & & 2.2 & & 0.9 & & 1.3 & & 2.3 \\
\hline \multicolumn{13}{|c|}{$\begin{array}{l}\text { Grow cultivars that head } \\
\text { at different times }\end{array}$} \\
\hline Yes & & 10.0 & & 40.6 & & 47.9 & & 5.4 & & 17.7 & & 10.1 \\
\hline No & & 19.8 & & 25.5 & & 45.6 & & 6.5 & & 15.4 & & 8.5 \\
\hline Maximum SE & & 2.8 & & 11.4 & & 4.1 & & 1.6 & & 3.1 & & 4.1 \\
\hline \multicolumn{13}{|c|}{ Stagger planting dates } \\
\hline Yes & & 10.4 & & 18.8 & & 53.1 & & 7.1 & & 21.3 & & 14.4 \\
\hline No & & 20.1 & & 29.3 & & 44.6 & & 6.4 & & 15.0 & & 7.9 \\
\hline Maximum SE & & 2.4 & & 5.5 & & 3.6 & & 1.7 & & 3.3 & & 4.0 \\
\hline
\end{tabular}

grow MR cultivars, apply a recommended fungicide with FHB as the primary target, rotate to never or rarely grow wheat following a small grain or corn crop, grow cultivars that head at different times, and stagger planting dates to spread out flowering (Supplementary Table S7). This question was distinct from those in which respondents were asked to name specific cultivars and fungicides (Tables 2, 3, 4, and $6)$. In addition, growers were asked if they had used an FHB risk forecasting website in the last 5 years.

HRS was the only market class that showed a strong positive association between higher MR cultivar use and the use of other FHB management practices, including the risk forecasting website, application of a recommended FHB-targeted fungicide, and rotation (Table 10). In no wheat market class was greater use of cultivar resistance associated with techniques to spread out flowering timing, in particular planting of cultivars with different heading dates or staggering planting dates.

For barley, greater use of MR cultivars was surprisingly associated with nonuse rather than use of other FHB management practices (Table 10). The reverse and expected trend occurred for HRS: those who had greater use of cultivar resistance also reported using several other management practices. The only other association between higher MR cultivar use and another management practice was among SWW growers, who applied a recommended fungicide.

Factors associated with best-fungicide adoption. Nearly all demographic, information access, and management factors were associated with whether a grower named one of the most effective DMIs as the fungicide applied most recently when FHB was the primary target (Table 11). Factors positively associated with higher percentages of respondents naming one of those fungicides included larger farms, higher yields, reduced tillage, greater experience of FHB problems, college education, internet access, use of the forecasting website, and use of FHB management practices. The highest percentages of those naming one of the most effective fungicides were found among farmers with crop consultants or chemical companies as their primary source of information, and use of risk forecasts and alerts rather than print media as their primary method of obtaining FHB information.

Barriers to use of management practices. Growers were asked to select, from among 10 possible barriers to FHB management, all that they had experienced. They could also name another barrier not provided. In order of frequency, the four most often cited barriers were weather preventing timely application of fungicide, timely fungicide application hindered by logistics such as crop area or applicator availability, and the difficulty determining flowering stage to properly time fungicide (Table 12). Weather in particular was the most frequently named barrier, with $19 \%$ of all respondents citing it. Two barriers reported with intermediate frequency were FHB ratings of varieties not being available in a timely manner and FHBreducing rotations not being practical.

Even for barriers named by relatively few growers overall, some states had higher percentages (Table 12). For example, for timely FHB ratings not being available, overall $9 \%$ of growers said that had limited their adoption, but states with higher figures were Kentucky with $25 \%$ and New York with $13 \%$. Difficulty in determining when crops were at the right stage of flowering to correctly time fungicide application was cited by $10 \%$ of respondents overall as a barrier, but the percentages were 16,15 , and $13 \%$ in North Dakota, Illinois, and Ohio, respectively. In North Dakota, 20 to $21 \%$ of respondents in each of four of the nine districts (Northeast, North Central, Northwest, and Central districts) named this problem with assessing flowering timing as a barrier (data not shown). The impracticality of rotating so that small grains did not follow corn or small grain crops was named by $9 \%$ of all responding growers as a barrier, but the percentage varied from $6 \%$ (Arkansas, Nebraska, and South Dakota) to $17 \%$ (Maryland).

Difficulty in obtaining the most effective fungicides for FHB management was regarded by only $2 \%$ of respondents overall as a barrier. Of the 5,107 total respondents, about 10\% (509 respondents) responded to the barriers question by saying they did not have an FHB problem or were not informed or involved in FHB management.

\section{Discussion}

Managing crop diseases that are episodically destructive is in some ways more difficult than those that cause damage every year. FHB has greatly extended its range in the United States since the 1990s, and every year it causes losses in some parts of that range but not everywhere (USWBSI, https://scabusa.org/publications\#pubs_articles). Although grain purchasers, extension specialists, and other crop advisors are closely attuned to FHB risk every year, most growers experience a damaging FHB epidemic only occasionally. The sporadic quality of FHB damage is particularly attributable to the monocyclic nature of the disease and to the variability of weather during the relevant crop growth stages. When FHB strikes, it can be catastrophic for growers and end-users alike, but any given location 
Table 11. Estimated percentages of over 5,000 wheat and barley producers in 17 U.S. states who named one of the most effective demethylation inhibitors (DMIs) as the fungicide applied most recently when Fusarium head blight (FHB) was the primary target, shown by demographic factors and FHB history indicators ${ }^{\mathrm{a}}$

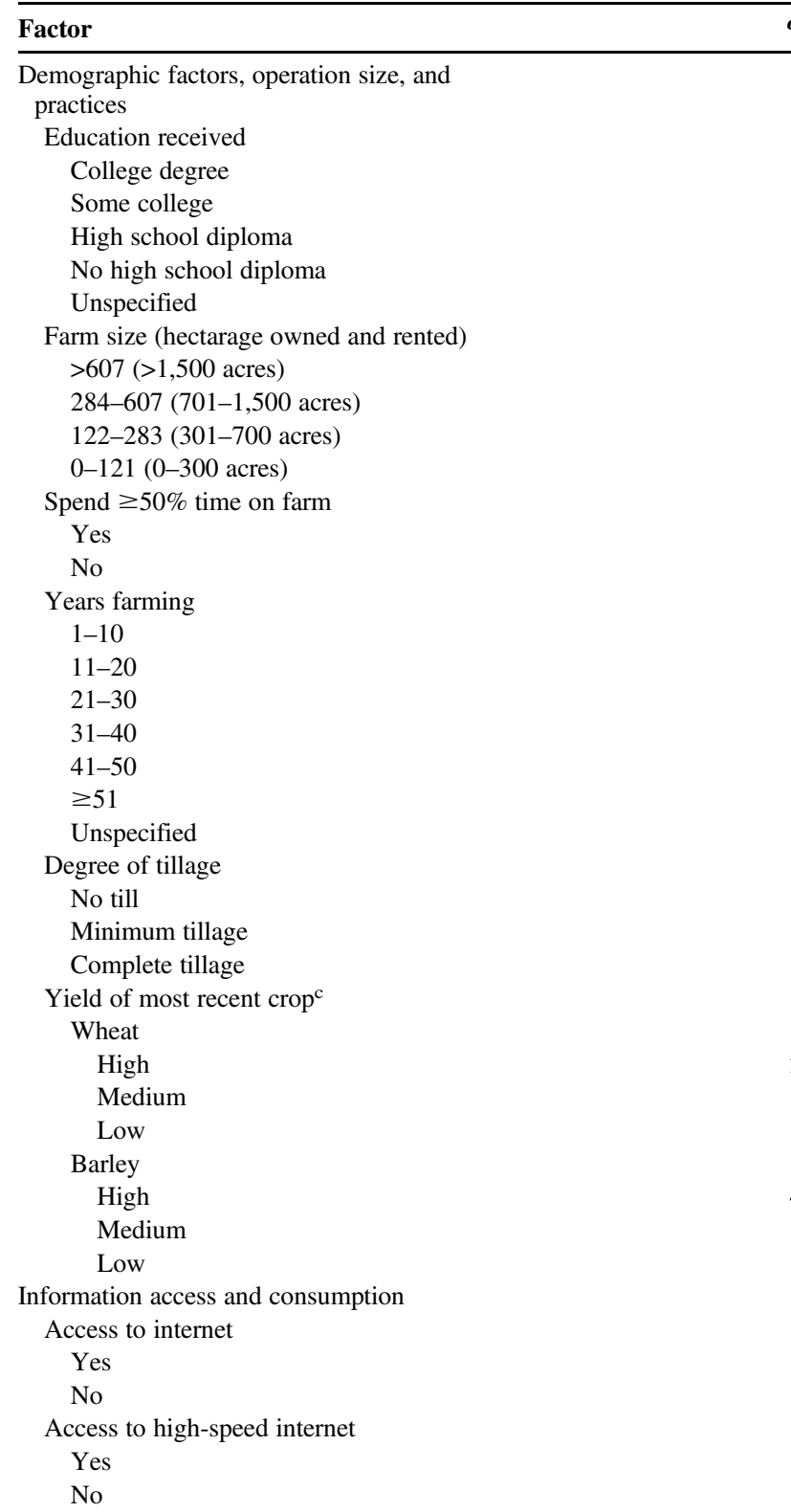

(Continued)

${ }^{a}$ Estimates are percentages of respondents who named one of the most effective DMIs, which were metconazole, prothioconazole, and prothioconazole plus tebuconazole; responses were either active ingredients or product names.

${ }^{b}$ Standard errors of estimates were always $<4.5$ except yield of most recent barley crop (7.5) and maximum of FHB problem years (7.0).

${ }^{\mathrm{c}}$ High: wheat $=\geq 901 \mathrm{~kg} \mathrm{~m}^{-3}\left(\geq 70 \mathrm{bu} \mathrm{ac}^{-1}\right)$ and barley $=\geq 1,287 \mathrm{~kg} \mathrm{~m}^{-3}$ $\left(\geq 100 \mathrm{bu} \mathrm{ac}^{-1}\right)$; medium: wheat $=515$ to $888 \mathrm{~kg} \mathrm{~m}^{-3}$ (40 to $\left.69 \mathrm{bu} \mathrm{ac}^{-1}\right)$ and barley $=644$ to $1,274 \mathrm{~kg} \mathrm{~m}^{-3}\left(50\right.$ to $\left.99 \mathrm{bu} \mathrm{ac}^{-1}\right)$; and low: wheat $=0$ to $502 \mathrm{~kg} \mathrm{~m}^{-3}\left(0\right.$ to $\left.39 \mathrm{bu} \mathrm{ac}^{-1}\right)$ and barley $=0$ to $631 \mathrm{~kg} \mathrm{~m}^{-3}$ ( 0 to $\left.49 \mathrm{bu} \mathrm{ac}^{-1}\right)$.

$\mathrm{d}$ Maximum indicates the highest number of years reported for any of the following: in the past 5 years, how many years has FHB reduced yields, caused a deoxynivalenol (DON) problem, or caused dockage or load rejection? Sum indicates the total years in all three responses. Years were 2009 to 2013 except in Kentucky, where they were 2010 to 2014.

e Growers could choose as many practices as applied; in the case of "apply a recommended fungicide," the percentages in the table (which reflect the specific fungicide reported elsewhere in the questionnaire) provide a crosscheck with claimed use of the practice. Similarly, recommended fungicides reported here could be cross-checked with specific fungicides used as reported in Table 6.
Table 11. (Continued)

Primary source of FHB

information

Crop consultants

Chemical companies

Extension/university

Grain buyers

Other farmers

Unspecified

Primary technology for FHB

information

Risk forecasting site

Text/e-mail to cell phone

E-mail alerts

Social media

Print publications

Unspecified

4

History of FHB problems

Maximum FHB problem years ${ }^{\mathrm{d}}$

$$
5
$$

3

2

1

Unspecified

Sum of FHB problem years ${ }^{\mathrm{d}}$

$\geq 7$

5-6

3-4

$0-2$

Unspecified

FHB reduced yield (years out of past 5 years)

$1-5$

FHB caused a DON problem (years out of past 5 years)

FHB caused dockage or load rejection (years out of past 5 years)

$1-5$

0

Use of FHB management practices

Used FHB forecasting website (in past 5 years)

Yes

No

Practices used to reduce FHB damage ${ }^{e}$

Grow MR cultivars

Yes

Apply a recommended fungicide with FHB as primary target

Yes

Rotate; never/rarely grow wheat after small grains or corn Yes

No

Grow cultivars that head at different times

Yes

No

Stagger planting dates

Yes 
only sees the problem on a random and usually infrequent basis, allowing FHB management to be eclipsed by other priorities.

This phenomenon was illustrated by the large percentages of survey respondents who indicated they had had no problems with FHB in the previous 5 years. It is of course possible that FHB took a minor toll on their crops that escaped notice. Nevertheless, in this first systematic national effort to quantify perceptions of wheat and barley growers about the disease, it emerged that the majority of growers perceive FHB occurrence as infrequent.

Managing an episodic crop disease is particularly difficult when cultivar resistance is an important feature of the management strategy, and grower genotype choice becomes a critical component. When the problem does not occur annually, consistent prioritization of cultivar resistance to that disease suffers, especially in regions where commercial cultivars turn over frequently, such as the eastern soft wheat region of the United States. In addition, other diseases sometimes cause growers to re-evaluate their priorities in selecting varieties. This was the case in southern Illinois and western Kentucky after 2016, when stripe rust damage occurred on a few popular soft wheat cultivars that had moderate resistance to FHB but were very susceptible to stripe rust (C. Bradley, personal observations). Some growers changed their priority from FHB resistance to stripe rust resistance after that, despite the fact that the former disease is more difficult to manage with fungicide than the latter.

From the data on use of resistant cultivars in relationship to other factors, it became clear that trends were very different among market classes, both in the degree of MR adoption and which factors were most likely to be associated with it. MR cultivar adoption was the strongest for HRS growers and cut across farm size, overall planted area, grower experience, internet access, and means of gaining information. The fact that relatively many North Dakotan growers prioritize FHB management is likely related to the devastating epidemic there in 1993, when yield losses were $45 \%$ and the economic impact was estimated to be $\$ 1$ billion (McMullen et al. 1997). Traditionally, small grains were the dominant crop for farmers in that area, so the impact was severe and memorable. A history of FHB-related yield loss has led HRS growers to respond by increasing MR crop area, and those who have taken that step report using other practices such as the forecasting website, a recommended fungicide, and rotation. Higher wheat yields are reported by HRS growers who indicate a higher percentage of MR acres, showing that not only was there not a yield penalty, but greater use of FHB resistance has been associated with improved yields in that market class.

By contrast, broadly speaking, FHB resistance was not prioritized as a criterion for cultivar selection in the SRW and SWW classes, despite the fact that FHB epidemics have become increasingly frequent across that region in the last 2 decades. The survey results show that for soft wheat growers, there is no relationship between a history of FHB problems and adoption of cultivar resistance, which itself is relatively weak. MR adoption does not vary in these market classes by farm size, wheat area, or technology used to access FHB-related information. There is also no significant relationship between yield and MR adoption, whether positive or negative.

One of the barriers to increasing production of cultivars MR to FHB in the soft wheat region was illustrated by the large percentage of both SRW and SWW growers who could not or did not name specific, recognizable wheat cultivars that they had recently grown. There are at least three possible explanations for this trend, which distinguishes these market classes from the others surveyed. One is that there is a widespread practice of farmers saving seed in this region (C. Cowger, personal observation), and survey respondents might not have known the cultivar most recently planted because seed had not been recently purchased. Another factor is that in contrast to hard wheat, durum, or barley, soft wheat is given lesser priority than other crops in the rotation by many of its growers (Warncke 2007; personal observations). Soft wheat can be an "afterthought" crop in relation to maize and soybeans, the other crops commonly

Table 12. Estimated percentages of various barriers to adoption of FHB management practices by wheat and barley growers in 17 states, when asked to check all that applya

\begin{tabular}{|c|c|c|c|c|c|c|c|c|c|c|c|}
\hline State & $\begin{array}{c}\text { Timely } \\
\text { FHB } \\
\text { ratings } \\
\text { of } \\
\text { varieties } \\
\text { not } \\
\text { available }\end{array}$ & $\begin{array}{l}\text { Seed of } \\
\text { FHB- } \\
\text { resistant } \\
\text { varieties } \\
\text { hard to } \\
\text { obtain }\end{array}$ & $\begin{array}{c}\text { Timely FHB } \\
\text { risk } \\
\text { information } \\
\text { hard to } \\
\text { obtain }\end{array}$ & $\begin{array}{c}\text { Hard to } \\
\text { determine } \\
\text { flowering } \\
\text { to } \\
\text { properly } \\
\text { time } \\
\text { fungicides }\end{array}$ & $\begin{array}{c}\text { FHB- } \\
\text { resistant } \\
\text { varieties } \\
\text { appear } \\
\text { lower- } \\
\text { yielding }\end{array}$ & $\begin{array}{l}\text { The most } \\
\text { effective } \\
\text { FHB } \\
\text { fungicides } \\
\text { too } \\
\text { expensive }\end{array}$ & $\begin{array}{l}\text { Weather } \\
\text { prevents } \\
\text { timely } \\
\text { application } \\
\text { of FHB } \\
\text { fungicides }\end{array}$ & $\begin{array}{c}\text { Timely } \\
\text { fungicide } \\
\text { application } \\
\text { hindered } \\
\text { for } \\
\text { logistical } \\
\text { reasons }^{\text {b }}\end{array}$ & $\begin{array}{l}\text { FHB- } \\
\text { reducing } \\
\text { rotation } \\
\text { not } \\
\text { practical }\end{array}$ & $\begin{array}{c}\text { Most } \\
\text { effective } \\
\text { fungicides } \\
\text { hard to } \\
\text { obtain }\end{array}$ & $\underset{\mathrm{SE}^{\mathrm{c}}}{\operatorname{Maximum}}$ \\
\hline Arkansas & 12 & 1 & 5 & 4 & 2 & 4 & 6 & 4 & 6 & - & 3.0 \\
\hline Illinois & 10 & 7 & 10 & 15 & 7 & 6 & 21 & 12 & 8 & 2 & 2.5 \\
\hline Indiana & 7 & 6 & 10 & 9 & 3 & 6 & 18 & 9 & 8 & 1 & 2.6 \\
\hline Kansas & 6 & 4 & 6 & 6 & 2 & 6 & 10 & 9 & 9 & 1 & 1.6 \\
\hline Kentucky & 25 & 13 & 10 & 9 & 11 & 9 & 20 & 9 & 7 & 2 & 4.0 \\
\hline Maryland & 10 & 7 & 8 & 9 & 6 & 6 & 17 & 12 & 17 & 0 & 2.8 \\
\hline Michigan & 10 & 5 & 7 & 11 & 4 & 6 & 19 & 13 & 8 & 1 & 2.2 \\
\hline Minnesota & 6 & 5 & 5 & 11 & 6 & 5 & 19 & 12 & 10 & 1 & 2.4 \\
\hline Missouri & 9 & 3 & 5 & 9 & 2 & 5 & 17 & 11 & 9 & 3 & 2.3 \\
\hline Nebraska & 8 & 5 & 2 & 4 & 3 & 5 & 6 & 2 & 6 & 0 & 1.9 \\
\hline New York & 13 & 7 & 8 & 5 & 3 & 6 & 18 & 16 & 12 & 1 & 3.2 \\
\hline $\begin{array}{l}\text { North } \\
\text { Carolina }\end{array}$ & 8 & 5 & 5 & 7 & 5 & 5 & 17 & 8 & 11 & 2 & 2.9 \\
\hline $\begin{array}{l}\text { North } \\
\text { Dakota }\end{array}$ & 9 & 7 & 7 & 16 & 13 & 8 & 33 & 21 & 14 & 2 & 1.9 \\
\hline Ohio & 7 & 8 & 8 & 13 & 4 & 9 & 24 & 8 & 9 & 2 & 2.1 \\
\hline Pennsylvania & 7 & 7 & 5 & 9 & 3 & 4 & 15 & 12 & 10 & 1 & 1.8 \\
\hline $\begin{array}{l}\text { South } \\
\text { Dakota }\end{array}$ & 6 & 3 & 3 & 10 & 5 & 5 & 12 & 10 & 6 & 1 & 1.9 \\
\hline Virginia & 8 & 4 & 5 & 7 & 7 & 9 & 15 & 12 & 8 & 2 & 3.3 \\
\hline All states & 9 & 6 & 6 & 10 & 5 & 6 & 18 & 11 & 9 & 2 & 0.6 \\
\hline
\end{tabular}

${ }^{a}$ Growers were also invited to name a different barrier. Of the 5,107 respondents, 509 indicated they did not have an FHB problem or were not informed about or involved in FHB management, 24 that they did not use fungicides, 22 that the techniques did not work or were too expensive, and 8 that FHB management was not important because of the end use of their crop. Estimates not reported where sample sizes were too small to calculate a standard error.

b Sample reasons: crop area too large, not enough time, or cannot engage a custom applicator in a timely way.

${ }^{c} \mathrm{SE}=$ maximum standard error of the estimates. 
rotated with it in the eastern United States. Finally, commercial eastern-U.S. soft wheat cultivars turn over frequently in the market, and the names of many of these cultivars consist of often-similar letters and numbers (e.g., Bruening 2018; Heiniger 2018), attributes that make these names harder to recognize and remember.

In durum wheat and barley, a possible reason for lower adoption of cultivar resistance in the United States is that the relative FHB resistance of durum cultivars is modest compared with, for example, spring wheat cultivars. For that reason, the most resistant durum cultivars are not termed MR, but rather a numerical rating system is used (Ransom et al. 2017). Durum growers may experience less motivation to adopt MR varieties than growers of spring wheats because the advantages are not as considerable. A similar dynamic may be at work in some barley-growing areas.

An additional factor significantly affecting cultivar selection in U.S. barley production is that much of the barley intended or used for malting is contracted with the buyer. Generally, those contracts are variety specific, so a grower may not have the option to select a cultivar that is MR. In fact, many of the cultivars approved by the American Malting Barley Association (2018) do not have an MR rating for $\mathrm{FHB}$.

With barley, we found significant differences between Minnesota and North Dakota on the one hand and the rest of the states on the other hand with regard to MR cultivar adoption. In Minnesota and North Dakota, larger farms had greater adoption of MR cultivars than smaller ones, whereas the reverse was true in other states. However, in Minnesota and North Dakota, growers who reported the largest hectarage of their top three barley cultivars tended to have lower rates of MR cultivar adoption, whereas the trend was also the reverse in the other states. We speculate that this difference may be attributable in part to the differences between the malting and feed barley markets, which have very different price structures and DON limits. North Dakota and Minnesota have large hectarages of both barley types, whereas nontraditional barley states in the eastern United States are aiming primarily for the malt markets and with relatively small hectarages. Other differences between these two groups of barley growers also complicate generalizations about how to improve FHB management.

Are branded cultivars, where some disease resistance data collected by the breeder may not remain attached to the marketed cultivar after a genetics company has licensed it, contributing significantly to growers' difficulty in selecting cultivars with moderate FHB resistance? Our data indicate that this is likely not a major factor. Whether two differently named cultivars were of the same or different genotypes, the majority (94 to 99\%) of cultivar-specific hectarage reported by our respondents was planted to cultivars for which ratings existed. In other words, systems for creating and publishing FHB ratings are working fairly well overall, whether or not multiple screened cultivars have the same genotype. Up to $25 \%$ of respondents in some states indicated that timely ratings were difficult to obtain, but the 17 -state mean for this problem was only $9 \%$.

There was also little evidence in these data that farm or operation size influences selection of cultivars MR to FHB. Only among HRW and durum growers was there a modest tendency for larger farms to grow a higher percentage of MR hectares.

Was there an association between use of a crop consultant and not knowing or not reporting which cultivars were grown? Across market classes, we found the reverse: those who had employed a crop consultant in the past 5 years to provide advice on their wheat or barley were significantly more likely to give identifiable names of cultivars they had recently grown (instead of no response or responses classified as "unknown cultivar"). Across all wheat market classes, $50 \%$ of farms that had not used consultants reported some or all "unknown cultivar" hectarage, compared with $45 \%$ of farms that had used consultants. The corresponding percentages of barley operations were 30 and $15 \%$, respectively.

Primary information source distinguished those who reported greater and lesser use of MR cultivars for all market classes except SWW. Reliance on extension and universities was associated with higher levels of MR use for four wheat classes (durum, HRS,
HRW, and SRW), but not for barley, where reliance on chemical companies and crop consultants was associated with higher MR use. For barley, primary information source did not significantly affect reported percentage of MR acreage among Minnesota and North Dakota growers, but in other states, there was higher use of MR barley cultivars among growers who relied on chemical companies than on those who prioritized extension/university sources for FHB information. Because MR use is generally low among barley growers, this suggests that extension and university personnel who reach out to these growers could give greater priority to information about managing FHB in barley, in order to increase the attention paid to MR cultivar use and other best management practices in that crop.

Crop consultants as a primary information source were associated with high levels of MR use in HRS and barley, and intermediate levels for HRW. In contrast, SRW growers grew a relatively low percentage of MR hectares if they had crop consultants as their primary FHB information source, but a relatively high percentage if they relied on extension/university sources. As for fungicide selection, growers with crop consultants (or chemical companies) as their primary information source were significantly more likely to name one of the most effective DMIs as the fungicide they last used against FHB; extension and university sources were in second place. This suggests that, outside the HRS and spring barley region, there has been more effective communication by crop consultants about fungicide choice than about the importance of planting MR cultivars.

Generally, the data indicate that there is a large need for grower education about selecting fungicides for FHB management. The majority of respondents in every state did not name a specific product, which may indicate a risk of making a suboptimal choice next time an FHB epidemic threatens, although many growers may have used a recommended product but not remembered the name. Kentucky and North Dakota were two states in which relatively large percentages of growers reported frequent FHB problems. Relatively many respondents in those two states also named a specific FHB-targeted fungicide, with higher frequencies than in other states for both the optimal best DMI products and the nonrecommended QoI-containing products. This pattern suggests that in areas where frequent FHB epidemics have occurred, growers are sensitized to the threat but not uniformly well informed regarding optimal fungicide selection. The task of agricultural educators is thus twofold: (i) to focus growers' attention on various stages of FHB management in a timely way and (ii) to ensure that crucial information is conveyed and assimilated, such as avoiding QoIs for FHB management. It is worth noting that in the HRS region, respondents who had higher wheat (although not barley) yields also more frequently cited one of the most effective DMIs as having been used for FHB management.

Moreover, although not a strong predictor of MR cultivar use, farm size was positively associated with respondents naming one of the most effective DMIs for FHB control. This trend suggests that there is a particular need to reach smaller farming operations with information about FHB fungicide selection. Education level was also positively associated with respondents naming one of the most effective DMIs.

Having only utilized a custom applicator for FHB-targeted fungicide applications was associated with a lower likelihood of naming one of the most effective DMI fungicides, which is not surprising. Many of those respondents' crops may have nevertheless been treated with one of the most effective products; the grower was simply leaving fungicide selection up to the applicator.

In the same vein, the data allowed us to ask whether the low percentage $(6 \%)$ of respondents who reported having used an FHB risk forecasting website during the past 5 years was attributable in part to reliance on crop consultants. Growers who contract with consultants to manage their crop might be relying on the latter to monitor risk, and our survey was not aimed at consultants, many of whom are likely utilizing FHB risk forecasts. Interestingly, however, $10 \%$ of those who had employed a crop consultant in the last 5 years to provide advice on wheat or barley production had also used an FHB risk forecasting site, whereas only $5 \%$ of nonconsultant users had used a 
risk forecasting site. In other words, those who had hired consultants to manage wheat and barley were twice as apt to directly monitor their own FHB risk as those who had not. This trend resembled the one regarding the ability to name recently grown cultivars, above.

Among the barriers to FHB management named by wheat and barley growers, different constituencies or entities may be able to tackle different barriers. Those problems without easy solutions include inclement weather or large crop areas hindering timely fungicide application. However, some factors are governed by commercial markets, such as the cost of the most effective fungicides and the availability of FHB-resistant wheat and barley seed, and these are areas in which private companies in the small-grain industry can have an impact.

The barriers that could be most readily addressed by extension personnel and crop consultants are the following three: timely FHB ratings of available wheat and barley cultivars, timely FHB risk information, and help in determining when crops are in the correct growth stage to optimize fungicide efficacy. Most of the surveyed states provide FHB ratings, so the variable is probably whether the ratings are reaching growers in a timely way. Growers obtain information about FHB from various sources and using various methods, so during the period of cultivar selection, FHB ratings should be promoted to growers using print and web-based technologies and called to their attention using e-mail and social media. With respect to FHB risk, most growers are not yet individually accessing web-based risk forecasts, so it is essential that they or their advisors sign up to receive texts and/or e-mails.

Surprisingly large percentages of growers in various states indicated that it is difficult to determine flowering dates in order to apply fungicides at the optimal time. It is worth devoting additional attention to materials and education to help growers and their advisors estimate flowering status for wheat crops, which can be challenging where there is unevenness in crop maturity for various reasons.

Although access to the internet was only strongly associated with increased use of cultivar resistance among SWW growers, there was a similar although weaker trend among growers of other wheat market classes. This suggests a need to expend additional resources to reach those without internet access, especially in states where access is relatively low such as Pennsylvania, Maryland, and New York.

The price of wheat and the costs of FHB (dockage, load refusal, selling the crop for feed instead of flour) factor into decisions about expenditures for management (e.g., using a more expensive DMI versus a less expensive one or no fungicide). These are complex questions on which there is little published research (but see Cowger et al. 2016). The purpose of this survey was to gain a basic understanding of the extent to which management practices were employed. The survey was judged too long to add questions about the economics of FHB management decisions beyond the one question on whether FHB-targeted fungicides were too expensive (Table 12). Those would be excellent topics for additional survey research.

In summary, the survey results highlighted success in adoption of best management practices for FHB in the HRS wheat class in particular. At the same time, the data illuminated challenges in other market classes, where use of more resistant cultivars is still weak. In the soft winter wheat region, states can serve as models that have relatively good levels of adoption, such as Missouri and New York for MR cultivars, or Kentucky and Illinois for education on using the most effective DMI fungicides for FHB management. In that region, the emphasis on variety selection needs to occur in mid- to late summer, long before the traditional fall and winter extension meetings.
Fungicide selection must be discussed at different times of year. For contracted sprays, the choice of product at flowering should be discussed with the applicator well in advance. Farmers who do their own spraying need to consider this in their product purchase strategies. Actual decisions to spray or not spray require guidance at the critical growth stages in the season, when internet and social media or visiting consultants have primacy. At appropriate times, national and local publicity may be helpful in overcoming the tendency for FHB management practices to fade from growers' awareness when the problem has not occurred recently.

\section{Acknowledgments}

We thank Sue Canty for considerable administrative work on the survey. We also thank those who helped develop the questionnaire, including Brian Ashford, Art Brandli, Don Hershman, Michele Marra, Pierce Paul, and Dave Van Sanford; NASS personnel for questionnaire development, sampling, Office of Management and Budget approval, and administration of the survey; and Selin Guney and Jared Stegall for statistical consultation.

\section{Literature Cited}

American Malting Barley Association. 2018. Recommended malting barley varieties. https://craftmalting.com/wp-content/uploads/2018/01/Recommend_ Varieties_2018.pdf

Bowman, D. T. 2013. Characteristics of North Carolina Wheat Varieties. North Carolina State University, Raleigh.

Bruening, B. 2018. Kentucky Small Grain Variety Testing Program. University of Kentucky, Lexington.

Cowger, C., Weisz, R., Arellano, C., and Murphy, P. 2016. Profitability of integrated management of Fusarium head blight in North Carolina winter wheat. Phytopathology 106:814-823.

Heiniger, R. 2018. NC measured crop performance-Small grains. https:// officialvarietytesting.ces.ncsu.edu/small-grains-2018/

Kolb, F., and Brucker, E. A. 2013. Multi-year average Fusarium head scab ratings of varieties. University of Illinois, Urbana-Champaign.

McMullen, M., Bergstrom, G., DeWolf, E. D., Dill-Macky, R., Hershman, D., Shaner, G., and Van Sanford, D. 2012. A unified effort to fight an enemy of wheat and barley: Fusarium head blight. Plant Dis. 96: 1712-1728.

McMullen, M., Jones, R., and Gallenberg, D. 1997. Scab of wheat and barley: A reemerging disease of devastating impact. Plant Dis. 81:1340-1348.

Nagelkirk, M. 2013. Considering Fusarium Head Scab When Selecting Wheat Varieties. Michigan State University Extension, East Lansing.

Paul, P., Bradley, C., Madden, L., Dalla Lana, F., Bergstrom, G., Dill-Macky, R., Esker, P., Wise, K., McMullen, M., Grybauskas, A., Kirk, W., Milus, E., and Ruden, K. 2018. Meta-analysis of the effects of QoI and DMI fungicide combinations on Fusarium head blight and deoxynivalenol in wheat. Plant Dis. 102:2602-2615.

Paul, P., McMullen, M., Hershman, D., and Madden, L. 2010. Meta-analysis of the effects of triazole-based fungicides on wheat yield and test weight as influenced by Fusarium head blight intensity. Phytopathology 100: 160-171.

Ransom, J., Elias, E., Friskop, A., Friesen, T., Liu, Z., Zhong, S., Manthey, F., Rickertsen, J., Eriksmoen, E., Hanson, B., Pradhan, G., Schatz, B., and Ostlie, M. 2017. North Dakota Durum Wheat: Variety Trial Results for 2017 and Selection Guide. Report No. A1067-17. North Dakota State University, Fargo.

U.S. Food and Drug Administration. 2010. Guidance for industry and FDA: Advisory levels for deoxynivalenol (DON) in finished wheat products for human consumption and grains and grain by-products used for animal feed. https://www.fda.gov/regulatory-information/search-fda-guidance-documents/ guidance-industry-and-fda-advisory-levels-deoxynivalenol-don-finished-wheatproducts-human

U.S. Wheat and Barley Scab Initiative. 2018. National annual summaries of FHB severity. https://scabusa.org/publications\#pubs_articles

Warncke, D. 2007. Benefits of Wheat in a Rotation. Crop Advisory Team Alerts. Michigan State University, East Lansing. 